Article

\title{
Administration of an Immune Stimulant during the Transition Period Improved Lipid Metabolism and Rumination without Affecting Inflammatory Status
}

\author{
Matteo Mezzetti ${ }^{1} \mathbb{1}$, Andrea Minuti $^{1}$, Fiorenzo Piccioli-Cappelli ${ }^{1}{ }^{\circledR}$, Gianfranco Gabai $^{2} \mathbb{(}$ and \\ Erminio Trevisi ${ }^{1, *(\mathbb{D})}$ \\ 1 Department of Animal Sciences, Food and Nutrition, Faculty of Agriculture, Food and Environmental \\ Science, Università Cattolica del Sacro Cuore, 29122 Piacenza, Italy \\ 2 Department of Comparative Biomedicine and Food Science, University of Padova, 35020 Legnaro (PD), Italy \\ * Correspondence: erminio.trevisi@unicatt.it; Tel.: +39-0523-599-278 or +39-3282-828-165; \\ Fax: +39-0523-599-276
}

Received: 23 July 2019; Accepted: 24 August 2019; Published: 28 August 2019

check for updates

Simple Summary: Immune stimulants are widely used to address immune dysfunctions that occur in transitioning dairy cows, reducing the likelihood they will develop infectious diseases. This study elucidates the effectiveness of an immune stimulant in promoting rumination recovery, reducing lipid mobilization and ketogenesis, and affecting the levels of circulating antioxidant systems in early lactation. These findings highlight the stimulant's potential effect in treating metabolic disorders of the transition period in dairy cows.

\begin{abstract}
Omnigen-AF (OAF) increases leukocyte functions in immunosuppressed animal models and reduces incidence of infectious diseases in early lactating dairy cows, although its mode of action is still unclear. This study aims to provide a wider perspective of the metabolic effect of OAF to test its potential as a strategy to address metabolic disorders of the transition period. A group of 10 Holstein dairy cows were divided into 2 groups: The treated group (IMS; 5 cows) received $32.5 \mathrm{~g}$ of OAF twice a day $\left(65 \mathrm{~g} \mathrm{~d}^{-1}\right)$ as top-dress in the morning and afternoon feeds from -55 to 42 days from calving (DFC), whereas the control group (CTR; 5 cows) received no supplementation. From -62 to 42 DFC, body condition score, body weight, dry matter intake, rumination time and milk yield were measured; blood samples were collected weekly to assess a wide hematochemical profile and to test white blood cell functions by ex-vivo challenge assays. At $30 \mathrm{DFC}$, rumen fluid was collected and analyzed for $\mathrm{pH}$, volatile fatty acids composition, urea nitrogen, and lactate contents. Data were submitted to ANOVA using a mixed model for repeated measures, including treatment, time, and their interaction as fixed effects. OAF decreased blood nonesterified fatty acids and beta hydroxybutyrate concentrations and increased rumination time in early lactation. Leukocytes from IMS cows had lower lactate production and lower glucose consumption after ex-vivo stimulation. OAF did not reduce the acute phase response indicators and reduced the blood concentrations of albumin and antioxidants after calving, suggesting impairment of hepatic functions related to protein synthesis and antioxidant management. Nevertheless, the lack of effect on bilirubin and liver enzymes refutes the possibility of severe liver damage occurring with OAF supplementation. Positive effects in reducing mobilization of body fats and ketogenesis and in increasing rumination time after calving suggest OAF effectiveness in preventing metabolic disorders of the transition period.
\end{abstract}

Keywords: immune stimulant; metabolic disorders; transition period; immune dysfunctions 


\section{Introduction}

The immune system eliminates sources of tissue injury, restores immune homeostasis, and returns tissues to their normal function [1]. Innate immunity defends the organism until lymphocytes develop antibodies against antigens [2]. During inflammation, polymorphonuclear cells (PMN) migrate with blood flow to peripheral tissues, starting the production of antibacterial reactive oxygen metabolites (ROM) through the respiratory burst process [3,4].

In PMNs of dairy cows, functions related to ROM production, myeloperoxidase activity, chemotaxis, and phagocytosis are impaired from 2-4 weeks prior through to approximately 2 weeks after parturition [5-7]. Consequently, cows become hyposensitive to antigens, and the incidence of infectious diseases increases [8,9]. From the early dry period to the first month of lactation, the immune system becomes unable to resolve inflammation $[10,11]$, triggering chronic phenomena $[7,12,13]$. The activation of leukocytes during chronic inflammation in combination with increased metabolic activity during the transition period could contribute to the production of oxidant species, depleting antioxidant defenses, and triggering oxidative stress $[1,14,15]$. Those conditions increase the development of metabolic disorders in the transition period $[16,17]$.

The immune stimulant Omnigen-AF (OAF) contains a mixture of active dried Saccharomyces cerevisiae, dried Trichoderma longibrachiatum fermentation product, niacin, vitamin B12, riboflavin-5phosphate, $d$-calcium pantothenate, choline chloride, biotin, thiamine monohydrate, pyridoxine hydrochloride, menodione dimethylpyrimidinol bisulfate, folic acid, calcium aluminosilicate, sodium aluminosilicate, diatomaceous earth, calcium carbonate, rice hulls, and mineral oil. It improves PMN functions in immunosuppressed goats that receive dexamethasone treatments [18], altering mRNA transcripts and protein expression related to the innate immune system $[19,20]$. Its mode of action has not been fully elucidated, but interactions between the yeast and fungal cell walls that compose OAF and the intestinal M-cells, mediating the response of lymphoid tissue, is a hypothetical mechanism [21]. Its administration in transition dairy cows down-regulated the expression of genes responsible for leukocyte death, inhibiting apoptosis and increasing the number of circulating leukocytes [6]. mRNAs encoding for cytokines were up-regulated, improving sensitivity of PMNs to extracellular signaling and cell-to-cell communication [18]. OAF also enhanced PMN diapedesis through the up-regulation of mRNA encoding for L-selectin [22] and augmented phagocytosis and respiratory burst by improving the oxidative phosphorylation pathway involved in ROM production $[6,20,23]$. Improved PMN functions account for the reduced incidence of mastitis found with OAF supplementation [6], suggesting its use as a potential strategy to reduce the incidence of infectious diseases in the transition period. However, no previous studies have investigated the effect of OAF on the sudden metabolic changes seen in the transition period, although elucidating such an effect is crucial in assessing the effectiveness of OAF in preventing metabolic disorders. Thus, the objective of our study was to assess the effect of supplemental OAF from dry-off to early lactation on metabolism, systemic inflammatory status, oxidative status, and immune status in dairy cows. We hypothesized that metabolic status around calving could be improved by OAF, mitigating systemic inflammation and oxidative status of treated animals.

\section{Materials and Methods}

The trial was carried out at the Università Cattolica del Sacro Cuore research dairy barn (Cerzoo Experiment Station, San Bonico, Piacenza, Italy) in accordance with Italian laws on animal experimentation (DL n. 116, 27/01/1992) and ethics (authorization of the Italian Ministry of Health N 65427; 29/10/2010-PR).

\subsection{Experimental Design and Animal Management}

A group of 10 Italian Holstein dairy cows (number of lactations: $1.9 \pm 1.1$; milk yield in the last lactation: $11547.8 \pm 2576 \mathrm{~kg}$; average lactation length: $353.1 \pm 54$ days [mean $\pm \mathrm{SD}$ ]) were housed in individual tied stalls under controlled environmental conditions (room temperature of $20^{\circ} \mathrm{C}$, relative 
humidity of $65 \%$, $14 \mathrm{~h}$ of light) from -62 to 42 days from calving (DFC). At -55 DFC cows were dried off and treated with a mammary antibiotic (Mamyzin A; Haupt Pharma Latina S.r.l., Borgo San Michele, Latina, Italy). Before dry-off and after calving, cows were milked twice a day at the stand at 4:00 am and 4:00 pm. All cows were individually fed a component diet of 2 equal meals of forages at 12-h intervals and 2-8 meals of concentrates supplied by computer feeder. Residuals were individually weighted after each meal, and the amount of DM offered was changed based on daily feed consumption. Before dry-off, animals received a lactating ration with soybean meal, alfalfa dehydrated hay, and corn silage (Phase 1). After dry-off, animals received only hay until -48 DFC. From -47 DFC to -7 DFC animals received a hay-based ration with soybean meal and corn silage (Phase 2). Seven days before the expected day of calving, $1 \mathrm{~kg}$ of lactation concentrate was gradually added to the diet (Phase 3). After calving the diet was enriched with $3 \mathrm{~kg}$ of alfalfa-dehydrated hay, and $2 \mathrm{~kg} \mathrm{week}^{-1}$ of corn silage was gradually added to the diet to a maximum of $20 \mathrm{~kg} \mathrm{~d}^{-1}$. Grass hay was gradually reduced to $2-2.5 \mathrm{~kg} \mathrm{~d}^{-1}$, and concentrate was increased by $0.5 \mathrm{~kg} \mathrm{~d}^{-1}$ to meet the requirement of $1 \mathrm{~kg}$ per $3 \mathrm{~kg}$ of milk produced (Phases 4 and 5). The same batches of hay and corn silage were used during the trial. Feeds were collected fortnightly; after dry matter determination, samples were pooled for subsequent analyses. Feeds and diet composition are shown in Table 1.

Table 1. Composition and characteristics of the experimental diets fed to cows during the 5 experimental phases.

\begin{tabular}{|c|c|c|c|c|c|}
\hline Diet, \% DM & Phase $1^{4}$ & Phase 2 & Phase 3 & Phase 4 & Phase 5 \\
\hline $\begin{array}{l}\mathrm{DFC}^{3} \\
\text { Item }\end{array}$ & -62 to -55 & -47 to -7 & -6 to 0 & 0 to 30 & 31 to 42 \\
\hline Corn silage & 28.5 & 18.6 & 23.6 & 24.0 & 23.3 \\
\hline Alfalfa hay & 16.4 & - & - & 13.7 & 11.1 \\
\hline Grass hay & 23.4 & 71.4 & 58.0 & 18.1 & 11.9 \\
\hline Concentrate $\left(-62\right.$ to $\left.0 \mathrm{DFC}^{3}\right)$ & - & 10.0 & 10.1 & 5 & - \\
\hline Concentrate $\left(1\right.$ to $\left.42 \mathrm{DFC}^{3}\right)$ & 31.7 & - & 8.3 & 44.2 & 53.7 \\
\hline \multicolumn{6}{|l|}{ Concentrate Composition, \% DM } \\
\hline Corn flour & - & - & - & 40.0 & 40.0 \\
\hline Barley flour & - & - & - & 1.4 & 1.4 \\
\hline Sorghum grain expanded & - & - & - & - & - \\
\hline Soybean meal & 90.5 & 90.5 & 90.5 & 13.1 & 13.1 \\
\hline Soybean dry rolled & - & - & - & - & - \\
\hline Sunflower meal & - & - & - & 4.9 & 4.9 \\
\hline Corn gluten feed & - & - & - & - & - \\
\hline Beet pulp & - & - & - & 16.6 & 16.6 \\
\hline Wheat bran & - & - & - & 9.8 & 9.8 \\
\hline Beet molasse slops & - & - & - & 2.6 & 2.6 \\
\hline Potato protein & - & - & - & 2.2 & 2.2 \\
\hline Hydrogenated palm oil & - & - & - & 3.3 & 3.3 \\
\hline Limestone & - & - & - & 1.39 & 1.39 \\
\hline Dicalcium phosphate & - & - & - & 1.80 & 1.80 \\
\hline Sodium bicarbonate & - & - & - & 0.98 & 0.98 \\
\hline Magnesium oxide & 2.2 & 2.2 & 2.2 & 0.64 & 0.64 \\
\hline Sodium Chloride & 1.4 & 1.4 & 1.4 & 0.32 & 0.32 \\
\hline Supplement ${ }^{1}$ & 5.9 & 5.9 & 5.9 & 1.07 & 1.07 \\
\hline \multicolumn{6}{|l|}{ Chemical Composition } \\
\hline $\mathrm{NE}_{\mathrm{L}}, \mathrm{Mcal} \mathrm{kg}$ of $\mathrm{DM}^{-1}$ & 1.59 & 1.45 & 1.53 & 1.60 & 1.63 \\
\hline Crude protein, \% DM & 14.9 & 13.6 & 14.5 & 16.2 & 17.2 \\
\hline Starch + sugar, \% DM & 23.7 & 16.8 & 19.3 & 26.0 & 18.3 \\
\hline Ether extract, \% DM & 3.80 & 1.80 & 2.40 & 4.48 & 5.08 \\
\hline NDF, \% DM & 39.4 & 49.3 & 45.5 & 35.7 & 32.6 \\
\hline $\mathrm{MP}^{2}, \% \mathrm{CP}$ & 9.8 & 9.1 & 9.7 & 10.5 & 11.1 \\
\hline $\mathrm{RUP}^{2}, \% \mathrm{DM}$ & 4.64 & 4.48 & 4.77 & 5.23 & 5.96 \\
\hline
\end{tabular}

${ }^{1}$ Supplements were composited to provide 150,000 IU of vitamin A, 10,000 IU of vitamin D, $200 \mathrm{mg}$ of vitamin E, $100 \mathrm{mg}$ of vitamin $\mathrm{K}, 100 \mathrm{mg}$ of vitamin $\mathrm{H} 1,50 \mathrm{mg}$ of vitamin B1, $0.5 \mathrm{mg}$ of vitamin B12, $500 \mathrm{mg}$ of vitamin PP, $4000 \mathrm{mg}$ of choline, $350 \mathrm{mg}$ of $\mathrm{Mn}, 800 \mathrm{mg}$ of $\mathrm{Zn}, 40 \mathrm{mg}$ of $\mathrm{Cu}, 20 \mathrm{mg}$ of I, $1 \mathrm{mg}$ of $\mathrm{Co}, 1 \mathrm{mg}$ Se. ${ }^{2}$ Estimated using NRC 2001. ${ }^{3}$ Days from calving. ${ }^{4}$ Between -55 and -48 days from calving cows received only grass hay. 
At dry-off, cows were divided into 2 homogeneous groups by body condition score (BCS), body weight (BW), number of lactations, milk yield, and age. The group treated with immune stimulant (IMS; 5 cows) received $32.5 \mathrm{~g}$ of Omnigen-AF ${ }^{\circledR}$ (Phibro Animal Health Corporation, Teaneck, NJ, USA) twice a day $\left(65 \mathrm{~g} \mathrm{~d}^{-1}\right)$ as top-dress on the morning and afternoon corn silage distribution, whereas the control group (CTR; 5 cows) received no supplementation. The amount of immune stimulant was determined on the basis of the average BW of the animals at dry-off to ensure the daily consumption of $9 \mathrm{~g}$ of product per $100 \mathrm{~kg}$ of BW was met. The daily consumption of the whole OAF dose provided was assessed by an operator after each meal. Between -62 and 42 DFC, periodic checks were performed, and blood samples were collected regularly according to the time schedule shown in Figure 1 and described in the following sections.

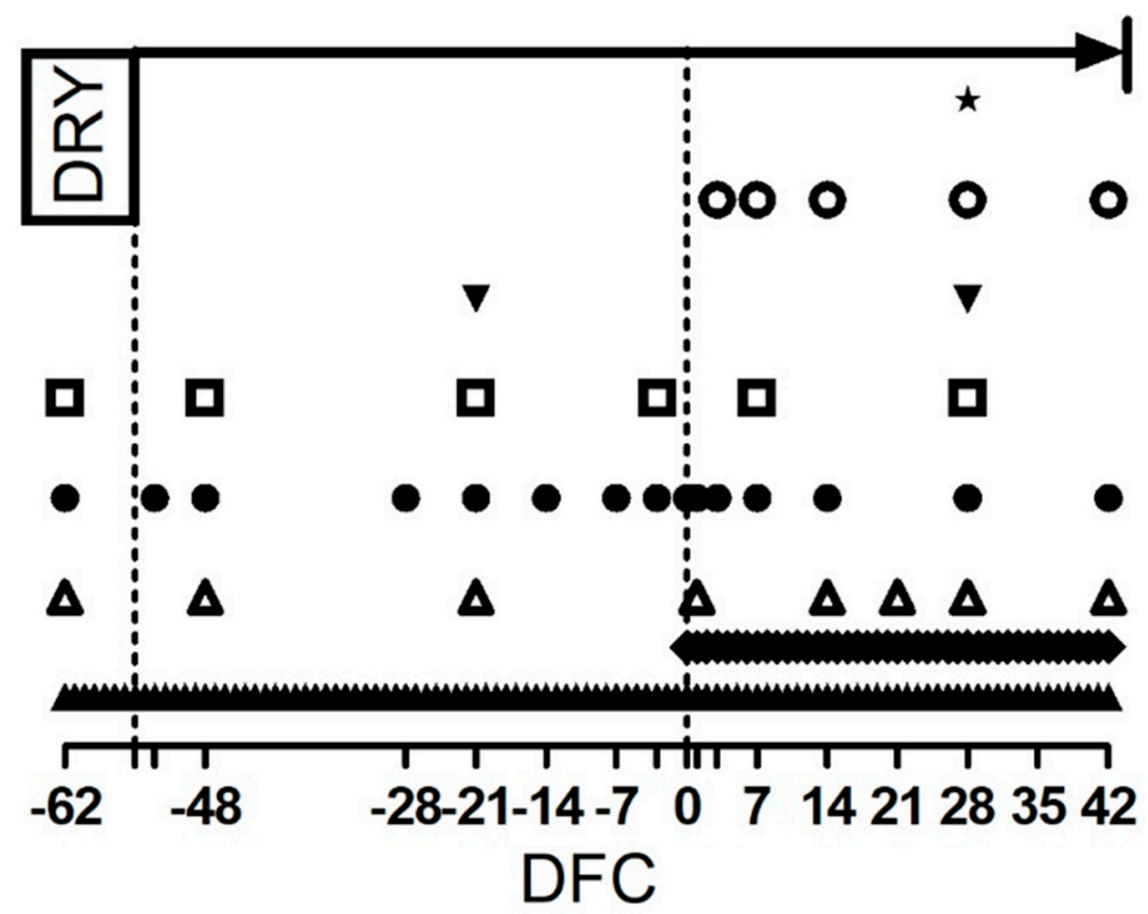

Figure 1. Scheduled time points, expressed as day from calving (DFC), for dry-off (DRY), treatment administration (upper arrow), rumen sample collection ( $)$, milk sample collection (O), and blood sample collection for the interferon gamma release assay $(\boldsymbol{\nabla})$, carrageenan skin test performance and blood cell profile and whole blood stimulation assay $(\square)$. Blood sample collection for metabolic profile (๑). Milk yield measurement $(\boldsymbol{)})$, body weight and body condition score determination $(\Delta)$, and dry matter intake and rumination time determination (A). Empty ticks indicate $-55,-53,-3,1$ and 3 DFC, respectively.

\subsection{Body Weight, Body Condition Score, Dry Matter Intake, Rumination Time, and Milk Yield}

The BW was measured in the morning, before feeding administration, with a single walk-in scale. BCS was determined by the same operator with a 1 to 4 scale [24], and its variation ( $\triangle \mathrm{BCS}$ ) was calculated as the difference between the value at calving day and at 28 DFC. The daily individual feed intake was measured by weighing the amount of feed administered and their refusals, and calculating the difference between them. The composition of refusal was also evaluated daily, and the DMI was calculated based on the DM content of each feed. Rumination time was registered using the Ruminact system (SCR Europe, Podenzano, PC, Italy), and data were processed according to [25]. Milk yield was weighed after each milking. Daily values of DMI, rumination time and milk yield were used to create an average weekly value. 


\subsection{Health Status}

Health conditions of cows were monitored daily from -62 to 42 DFC. Body temperature was measured daily with a rumen bolus (DVM System TempTrack ${ }^{\mathrm{TM}}$, HerdStrong, LLC, Greeley, CO, USA). Mastitis was diagnosed by visual evaluation of abnormal milk from each quarter and by somatic cell count (SCC) analysis in suspicious cases. Retained placenta was diagnosed when the fetal membranes were not expelled within $24 \mathrm{~h}$ after calving. Endometritis and metritis were diagnosed according to [26]. Milk fever, displacement of abomasum, and pneumonia were diagnosed by examination by a veterinary practitioner. Diarrhea was diagnosed by visual evaluation of feces consistency and color according to the fecal score method [27], assuming diarrheic feces to have a fecal score $\leq 2$. Sub-clinical ketosis was retrospectively diagnosed based on blood levels of beta-hydroxybutyrate (BHB), assuming a threshold of $1.4 \mathrm{mMol} / \mathrm{L}$ as a cut-off point [28].

\subsection{Blood Sample Collection}

Blood samples were harvested trough jugular venipuncture in evacuated collection tubes (BD Vacutainer; BD and Co., Franklin Lakes, NJ, USA) before the morning feeding. Samples were used for different assays (Figure 1) and processed according with the following sections. After all blood samples were collected, all frozen samples were thawed and analyzed (maximum storage time of 6 months).

\subsubsection{Metabolic Profile Assessment}

Samples were collected into heparinized tubes and processed as described by [29]. After processing, plasma samples were stored at $-20^{\circ} \mathrm{C}$. A clinical auto-analyzer (ILAB-650, Instrumentation Laboratory, Lexington, MA, USA) was used to determine the concentration of glucose, nonesterified fatty acids (NEFA), $\mathrm{BHB}$, urea, creatinine, $\mathrm{Ca}, \mathrm{P}, \mathrm{Mg}, \mathrm{Na}, \mathrm{K}, \mathrm{Cl}, \mathrm{Zn}$, aspartate amino transferase-glutamate oxaloacetate transaminase (AST-GOT), gamma glutamyl transferase (GGT), alkaline phosphatase (ALP), total protein, haptoglobin, ceruloplasmin, albumin, total bilirubin, cholesterol, and globulin in accordance with [29]. Furthermore, ROM, ferric-reducing antioxidant power (FRAP), nitrate $\left(\mathrm{NO}_{3}\right)$, nitrite $\left(\mathrm{NO}_{2}\right)$, and nitric oxides (NOx) were determined according to [30], paraoxonase (PON) according to [12], thiol groups (SHp) according to [31], myeloperoxidase according to [32], and advanced oxidation protein products (AOPP) according to [33]. The ROM/FRAP ratio was also calculated to provide an integrated oxidant status index according to current recommended practices [34]. Finally, L-lactic acid (LLA) and D-lactic acid (DLA) were determined with a commercial kit (K-DLATE, Megazyme Co., Wicklow, Ireland).

Calibration was performed through commercial standards for $\mathrm{Na}, \mathrm{K}, \mathrm{Cl}, \mathrm{Zn}$, ceruloplasmin, albumin, protein, bilirubin, ALP, NEFA, BHB, ROMt, FRAP, DLA, LLA, and nitrogen species. Calibration for remaining indicators was performed through internal standards. Four different quality controls were used to test the repeatability and precision for each parameter during each assay. A multi-detection microplate reader (BioTek Synergy 2, Winooski, VT, USA) and commercial kits for ELISA were used to determine the concentration of IL-1 beta (IL-1B; ESS0029; Thermo Scientific, Frederick, MD, USA) and IL-6 (ESS0027; Thermo Scientific) according to [7] and those of serum amyloid alpha (SAA; TP-802, Tridelta D.L., Ireland). Oxygen-reactive antioxidant capacity (ORAC) was determined with a fluorimetric method according to [30]. Retinol, tocopherol, and beta-carotene were analyzed by reverse-phase HPLC (LC-4000, Jasco Europe, Carpi MO, Italy), as described by [7]. Further details on the analytical procedures adopted in blood analysis are reported in Supplementary File 1.

\subsubsection{Blood Cell Profile}

Samples were collected in K-EDTA tubes, kept at $4{ }^{\circ} \mathrm{C}$ after collection and analyzed within $4 \mathrm{~h}$ of collection with Cell-DYN 3700 (Abbott Diagnostic Division, Santa Clara, CA, USA). A laser optic assay was used to determine the total leukocytes, neutrophils, lymphocytes, monocytes, eosinophils and basophils. The neutrophil to lymphocyte ratio was calculated. The amount of red blood cells, hematocrit, mean cell volume, red cell distribution width, number of platelets, and mean platelet volume 
were determined via electrical impedance assay. The amount of hemoglobin, mean cell hemoglobin, and mean cell hemoglobin concentration were determined using spectrophotometric assay.

\subsubsection{Whole Blood Stimulation Assay}

Samples were collected in heparinized serum tubes and processed according to [7]. Briefly, whole blood was freshly stimulated with 0 (baseline), 0.01 (low dose), and $5 \mu \mathrm{g} / \mathrm{mL}$ (high dose) of bacterial lipopolysaccharides (Escherichia coli O111:B4; Sigma-Aldrich Company Ltd., Gillingham, UK, Cat. No. L3012). After stimulation, all samples were positioned on a rotator within a heated incubator (Grant Boekel, HIR10 M) set to a temperature of $38^{\circ} \mathrm{C}$ and a rotation speed of 3 times/min for $3.5 \mathrm{~h}$. Plasma was collected after centrifugation at $8500 \times \mathrm{g}$ for $16 \mathrm{~min}$ at $4{ }^{\circ} \mathrm{C}$. After whole blood stimulation assay (WBA), plasma samples were stored at $-80^{\circ} \mathrm{C}$ for measurement of glucose, DLA, LLA, IL-1B, IL-6, $\mathrm{NOx}, \mathrm{NO}_{2}$, and $\mathrm{NO}_{3}$. Variation of plasma indicators after WBA with $\mathrm{L}$ and $\mathrm{H}$ doses of LPS were expressed as fold change relative to the baseline.

\subsubsection{Interferon Gamma Release Assay}

For the interferon gamma (IFNG) release assay, whole blood samples again were collected into heparinized tubes (Figure 1). After collection, the tubes were stored in a vertical position in a warm bath at a temperature of $38^{\circ} \mathrm{C}$ and transported to the laboratory within $20 \mathrm{~min}$ for the stimulation procedure. Whole blood was used in an IFNG release assay after Mycobacterium avium stimulation (internal method IZSLER, MP 13/011). Briefly, two 1-mL aliquots of each blood sample were distributed in a 24-well tissue culture microtiter plate. One well was supplemented with $100 \mu \mathrm{L}$ of a 1:10 dilution of Mycobacterium avium purified protein derivative (PPD, IZS Umbria e Marche, Perugia, Italy, $0.5 \mathrm{mg} / \mathrm{mL}$ ) and PBS, and 1 well contained $100 \mu \mathrm{L}$ of sterile PBS as control. The plate was positioned in a heated incubator (Grant Boekel, HIR10 M) set to a temperature of $38^{\circ} \mathrm{C}$ with a relative humidity of $95 \%$ for $24 \mathrm{~h}$. After incubation, the blood was centrifuged at $8500 \times \mathrm{g}$ for $16 \mathrm{~min}$ at $4{ }^{\circ} \mathrm{C}$, and plasma was stored at $-20^{\circ} \mathrm{C}$ until use. Plasma was later thawed and analyzed in a sandwich ELISA for bovine IFNG with two monoclonal antibodies, as previously described [35]. Results were evaluated in terms of optical density difference $(\triangle \mathrm{OD})$ between avian PPD-stimulated and control wells.

\subsection{Milk Sample Collection and Analysis}

Milk samples were collected into 100-mL polypropylene bottles (International Scientific Supplies Ltd., Bradford, UK) during the morning milking (Figure 1). Butterfat, protein, lactose, casein content, titratable acidity, and coagulation properties (rennet clotting time [rCT] and curd firmness at $30 \mathrm{~min}$ [a30]) were measured by using infrared instrumentation (MilkoScan FT 120, Foss Electric, Hillerød, Denmark) according to [36] and [37]. The output of fat and protein and the fat to protein ratio were also calculated. Urea nitrogen in skimmed milk was determined by a spectrophotometric assay, using a urea nitrogen kit (cat\# 0018255440, Instrumentation laboratory, Milano, Italy) in association with a clinical auto-analyzer (ILAB-650, Instrumentation Laboratory, Lexington, MA, USA). SCC were determined using an optical fluorimetric method with an automated cell counter (Fossomatic 180, Foss Electric).

\subsection{Carrageenan Skin Test}

The carrageenan skin test (CST) was performed as specified by [7] to evaluate peripheral immune response (Figure 1). Skin thickness was measured using a skinfold caliper (cat\# 470119-588, VWR, Radnor, PA, USA) immediately before carrageenan injection (day 0 ) and again at 2 and 9 days after the injection. The total response of each challenge was calculated as the area under the curve of the thickness measured at day 2 and day 9, subtracting the thickness measured at day 0 .

\subsection{Rumen Fluid Measurements}

Rumen samples were collected with an orogastric probe (Ruminator, Proofs Products, Guelph, ON, Canada) before the morning feed administration (Figure 1). To reduce the buffer effect of saliva, 
the first $0.5 \mathrm{~L}$ of rumen juice was discarded. The $\mathrm{pH}$ was immediately measured (GLP 21, Crison Instrument SA, Alella, Barcellona, Spain, ESP). A 2-mL aliquot of the supernatant was transferred into tubes containing $1 \mathrm{~mL}$ of $0.12 \mathrm{M}$ oxalic acid and immediately frozen at $-20{ }^{\circ} \mathrm{C}$ for later analysis. Total VFA concentration and molar proportion of acetic, propionic, butyric, iso-butyric, valeric, iso-valeric, caproic, iso-caproic, and enanthic acids were analyzed as previously described [31]. Single VFA were expressed as relative amounts compared with total VFA concentration. A spectrophotometric clinical auto-analyzer (ILAB-650, Instrumentation Laboratory, Lexington, MA, USA) and commercial kits for urea nitrogen (cat\# 0018255440, Instrumentation laboratory, Milano, Italy) and lactate (K-DLATE, Megazyme Co., Wicklow, Ireland) were used to assess the concentration of ammonia-N and of LLA, DLA and total lactic acid, respectively.

\subsection{Statistical Analysis}

A limitation of our study was the small sample size; thus, a post hoc power analysis considering an alpha value of 0.05 was run on the measurements included in current results. High power $(1-\beta>0.8)$ was found for IL1B, IL6, cholesterol, Zn, Albumin, PON, FRAP, AOPP, tocopherol, thiol groups, myeloperoxidase, and NEFA. The remaining measurements had a moderate power $(0.5<1-\beta<0.4)$. Data were analyzed in SAS software, version 9.4 (SAS Inst. Inc., Cary, NC, USA) and are presented in the graphs and tables as means and pooled standard error for individual means of treatments over time. Before analysis, normality of data distribution was verified for each parameter by evaluating skewness and kurtosis according to the Shapiro test in SAS. Non-normally distributed parameters were normalized through natural logarithms (for plasma measurements: IL-1B, IL-6, LLA, GGT, bilirubin, beta-carotene, $\mathrm{NOx}, \mathrm{NO}_{2}$, and $\mathrm{NO}_{3}$; for blood cell profile: eosinophils; for WBA: the fold change of IL-1B, IL-6, glucose, DLA, LLA, $\mathrm{NO}_{2}, \mathrm{NO}_{3}$, and NOx; the total response to CST; and for milk quality measurements: fat, fat output, fat/protein ratio, $\mathrm{rCT}$ and SCC) or square root transformation (for plasma measurements, the $\mathrm{BHB}$ ) and back transformed to be plotted in the graphs and tables.

Data on DMI, BW, BCS, rumination time, milk yield, plasma measurements, blood cell profile, WBA, milk quality measurements, response to IFNG release assay, and CST underwent ANOVA using a mixed model for repeated measures (Mixed procedure, SAS Inst. Inc., Cary, NC, USA) in accordance with [38]. The statistical model included the fixed effect of treatment (TRT; CTR and IMS), time (t) and their interaction $(\mathrm{TRT} \times \mathrm{t})$.

$$
\mathrm{y}_{\mathrm{ijk}}=\mu+\alpha_{\mathrm{i}}+\delta_{\mathrm{ij}}+\tau_{\mathrm{k}}+(\alpha \tau)_{\mathrm{ik}}+\mathrm{e}_{\mathrm{ijk}}
$$

where $y_{i j k}$ is the response at time $k$ on animal $j$ in treatment group $i, \mu$ is the overall mean, $\alpha_{i}$ is a fixed effect of treatment $i, \delta_{i j}$ is a random effect of animal $j$ in treatment group $i, \tau_{k}$ is a fixed effect of time $k,(\alpha \tau)_{i k}$ is a fixed interaction effect of treatment $i$ with time $k$, and $e_{i j k}$ is random error at time $k$ on animal $\mathrm{j}$ in treatment $\mathrm{i}$. For parameters that were measured daily (DMI, rumination time, and milk yield), the time effect considered the average weekly value; for other parameters (BW, BCS, plasma measurements, blood cell profile, WBA, milk quality measurements, IFNG release assay, and CST), it considered single DFC. The time was considered as a repeated measure within the cow, and the cow was assumed as a random effect. For WBA, the dose (D; low and high) and the full interaction effect $($ TRT $\times \mathrm{t} \times \mathrm{D})$ also were considered. The analysis was carried out using three covariance structures: autoregressive order, compound symmetry, and spatial power with their heterogeneous counterparts. When a heterogeneous covariance structure was chosen, the bars errors for each time point have been provided in the figures. These were ranked according to their Akaike information criterion, with the structure that had the lowest Akaike information criterion being chosen [38]. A preliminary analysis was conducted, and all parameters were covariate using data collected at -62 DFC as the baseline. The covariate was included in the final model only for parameters that had a significant covariate effect in the preliminary analysis, adopting $p \leq 0.1$ as a cutoff for covariate inclusion (among plasma measurements: glucose, IL-1B, IL-6, cholesterol, retinol, and tocopherol).

Data on rumen fluid measurements were analyzed by the same procedure (Mixed procedure, SAS Inst. Inc., Cary, NC, USA), considering only the fixed effect of TRT. 
After the analysis, the residuals were plotted to assess for model assumptions of normality and homoscedasticity. The post-hoc comparison between treatments was done using the F-test and are discussed when the $p$-value for main effect was $p \leq 0.05$. Main effects at $p \leq 0.10$ are discussed in the context of tendencies. Differences between treatments at single time points are discussed at $p \leq 0.10$ for the main interaction effect.

\section{Results}

The time effect was highly significant $(p<0.01)$ for most of the parameters included in the study. Thus, the time effect will not be presented in the Results section.

\subsection{Body Weight, Body Condition Score, Dry Matter Intake, Rumination Time, and Milk Yield}

No TRT effect appeared for DMI, rumination time or milk yield (Figure $2 \mathrm{a}-\mathrm{c}$ ), but a TRT $\times \mathrm{t}$ interaction appeared for DMI and rumination time $(p<0.01)$. The DMI tended to be lower in the IMS group than in the CTR group at 5 weeks from calving $(p<0.10)$. Rumination time was higher in the IMS group than in the CTR group at 3 and 6 weeks from calving $(p<0.05)$ and tended to be higher at 7 weeks from calving $(p<0.10)$. No effect was detected on body weight or BCS (Supplementary File 2).
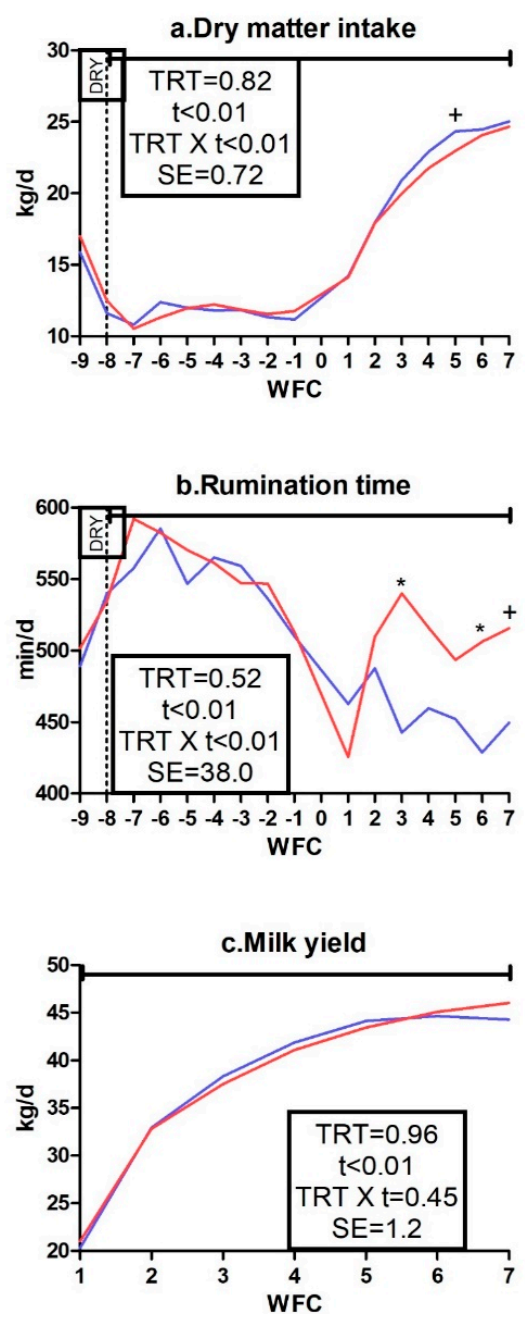

Figure 2. Average week values of dry matter intake (a), rumination time (b), and milk yield (c) in control dairy cows (CTR; blue line, $\mathrm{n}=5$ ) and cows receiving $65 \mathrm{~g}^{*} \mathrm{~d}^{-1}$ of Omnigen-AF ${ }^{\circledR}$ as top-dress (IMS; red line, $n=5$ ) between -55 and 42 days from calving. Upper solid line indicates timing of treatment administration. TRT is treatment effect; $\mathrm{t}$ is time effect; TRT $\times \mathrm{t}$ is the treatment $\times$ time interaction effect (+ is $p<0.10)$. WFC is weeks from calving; DRY is dry-off day ( -55 days from expected calving). SE is standard error. 


\subsection{Milk Quality and Rumen Fluid Measurements}

Among milk quality and rheological measurements (Table 2), lactose had a significant TRT $\times$ $\mathrm{t}$ interaction $(p=0.03)$ and tended to be higher in the IMS group than in the CTR group at 7 DFC $(p<0.10)$. No effect appeared for the other milk measurements or rumen fluid measurements (Table 3 ).

Table 2. Milk composition, rheological measurements, and somatic cell count in control dairy cows $(n=5)$ or cows receiving $65 \mathrm{~g}^{*} \mathrm{~d}^{-1}$ of Omnigen-AF${ }^{\circledR}$ as top-dress between -55 and 42 days from calving $(n=5)$.

\begin{tabular}{|c|c|c|c|c|c|c|c|c|c|}
\hline \multirow{2}{*}{ Item, Unit } & \multirow{2}{*}{ TRT $^{1}$} & \multicolumn{4}{|c|}{ Days from Calving } & \multirow{2}{*}{$\mathrm{SE}^{5}$} & \multicolumn{3}{|c|}{$p$-Value } \\
\hline & & 7 & 14 & 28 & 42 & & TRT $^{1}$ & $t^{2}$ & TRT $\times t^{3}$ \\
\hline \multirow{2}{*}{$\begin{array}{c}\text { Butterfat, } \\
\text { mg } 100 \mathrm{~mL}^{-1}\end{array}$} & CTR & 4.69 & 4.24 & 4.68 & 3.67 & 0.35 & 0.21 & 0.01 & 0.78 \\
\hline & IMS & 4.33 & 4.14 & 3.82 & 3.36 & & & & \\
\hline \multirow{2}{*}{ Fat output, kg } & CTR & 0.38 & 0.41 & 0.65 & 0.48 & 0.07 & 0.17 & 0.02 & 0.65 \\
\hline & IMS & 0.27 & 0.37 & 0.48 & 0.44 & & & & \\
\hline \multirow{2}{*}{$\begin{array}{l}\text { Total protein, } \\
\mathrm{mg} 100 \mathrm{~mL}^{-1}\end{array}$} & CTR & 3.84 & 3.30 & 3.07 & 3.09 & 0.10 & 0.49 & $<0.01$ & 0.66 \\
\hline & IMS & 3.81 & 3.34 & 3.25 & 3.19 & & & & \\
\hline \multirow{2}{*}{ Protein output, kg } & CTR & 1.21 & 1.18 & 1.33 & 1.36 & 0.06 & 0.61 & $<0.01$ & 0.15 \\
\hline & IMS & 1.15 & 1.18 & 1.38 & 1.50 & & & & \\
\hline \multirow{2}{*}{ Fat/protein ratio, - } & CTR & 1.22 & 1.28 & 1.54 & 1.19 & 0.12 & 0.11 & 0.11 & 0.64 \\
\hline & IMS & 1.14 & 1.24 & 1.19 & 1.05 & & & & \\
\hline \multirow{3}{*}{$\begin{array}{c}\text { Lactose, } \\
\text { mg } 100 \mathrm{~mL}^{-1}\end{array}$} & CTR & 4.79 & 5.25 & 5.06 & 5.17 & 0.07 & 0.73 & $<0.01$ & 0.03 \\
\hline & IMS & 4.96 & 5.09 & 5.16 & 5.14 & & & & \\
\hline & & + & & & & & & & \\
\hline \multirow{2}{*}{ 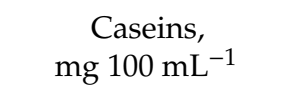 } & CTR & 2.84 & 2.50 & 2.28 & 2.33 & 0.08 & 0.42 & $<0.01$ & 0.59 \\
\hline & IMS & 2.85 & 2.51 & 2.45 & 2.40 & & & & \\
\hline \multirow{2}{*}{$\begin{array}{l}\text { Titratable acidity, } \\
{ }^{\circ} \mathrm{SH} 50 \mathrm{~mL}^{-1}\end{array}$} & CTR & 3.96 & 3.33 & 3.23 & 3.12 & 0.17 & 0.77 & $<0.01$ & 0.93 \\
\hline & IMS & 3.86 & 3.19 & 3.20 & 3.12 & & & & \\
\hline \multirow{2}{*}{ Urea-N, mg dL ${ }^{-1}$} & CTR & 31.2 & 34.7 & 26.8 & 31.2 & 3.11 & 0.64 & 0.08 & 0.66 \\
\hline & IMS & 33.7 & 33.3 & 30.2 & 33.0 & & & & \\
\hline \multirow{2}{*}{$\begin{array}{l}\text { Coagulation time } \\
(\mathrm{rCT}), \mathrm{min}\end{array}$} & CTR & 12.3 & 20.0 & 14.0 & 14.5 & 2.03 & 0.77 & $<0.01$ & 0.68 \\
\hline & IMS & 11.5 & 16.2 & 14.8 & 16.1 & & & & \\
\hline \multirow{2}{*}{$\begin{array}{l}\text { Curd firmness (a30), } \\
\mathrm{mm}\end{array}$} & CTR & 37.7 & 23.2 & 35.3 & 32.8 & 4.59 & 0.27 & 0.31 & 0.40 \\
\hline & IMS & 43.4 & 33.6 & 35.6 & 34.7 & & & & \\
\hline \multirow{2}{*}{$\mathrm{SCC}^{4}, 10^{3} \mathrm{~mL}^{-1}$} & CTR & 293.4 & - & 37.7 & - & 91.4 & 0.47 & 0.18 & 0.31 \\
\hline & IMS & 72.4 & - & 54.9 & - & & & & \\
\hline
\end{tabular}

${ }^{1}$ Treatment (CTR is control cows; IMS is cows receiving a topdressing of the feeds with the immunostimulant Omnigen-AF $\left.{ }^{\circledR}\right) .{ }^{2}$ Time. ${ }^{3}$ Treatment $\times$ time interaction $(+$ is $p<0.10$ for differences among means within a column. This symbol is only presented when the interaction effect is significant). ${ }^{4}$ Somatic cells count. ${ }^{5}$ Standard error $=$ larger standard error for the fixed effects.

\subsection{Metabolic Profile}

\subsubsection{Packed Cell Volume, Energy, Protein, and Mineral Metabolism Biomarkers}

Among energy metabolism biomarkers, IMS cows tended to have lower concentration of NEFA $(p=0.06$; Figure 3a). A significant TRT $\mathbf{X} \mathrm{t}$ interaction was detected for BHB $(p<0.04$; Figure 3b) and the interaction for LLA trended toward significance ( $p=0.07$; Figure $3 c)$. In comparison to CTR cows, IMS cows had a lower BHB concentration at 14 DFC $(p<0.01)$ and tended to have a lower LLA concentration at -21 and $42 \mathrm{DFC}(p<0.10)$. No effect was detected on the packed cell volume or on glucose and DLA concentrations (Supplementary File 3a-c).

Among protein metabolism biomarkers, creatinine was affected by TRT $(p<0.01)$ and the TRT $\times \mathrm{t}$ interaction trended toward significance ( $p=0.06$; Figure $3 \mathrm{~d})$, resulting in a lower concentration in IMS cows than in the CTR group between -28 and -3 DFC and from 7 DFC to the end of the experimental period $(p<0.05)$. No effect was detected on urea concentration (Supplementary File 3d). 
Table 3. Ruminal $\mathrm{pH}$, ammonia concentrations and volatile fatty acids molar proportion, determined at 28 days after calving in control dairy cows $(n=5)$ or cows receiving $65 \mathrm{~g}^{*} \mathrm{~d}^{-1}$ of Omnigen-AF ${ }^{\circledR}$ as top-dress between -55 and 42 days from calving $(n=5)$.

\begin{tabular}{|c|c|c|c|c|c|}
\hline \multirow{2}{*}{ Item } & \multirow{2}{*}{ Unit } & \multicolumn{2}{|c|}{ TRT $^{1}$} & \multirow{2}{*}{$\mathrm{SE}^{3}$} & \multirow{2}{*}{$p$-Value } \\
\hline & & CTR & IMS & & \\
\hline $\mathrm{pH}$ & - & 6.78 & 6.54 & 0.15 & 0.14 \\
\hline Ammonia-N & $\mathrm{mg} \mathrm{L}^{-1}$ & 4.65 & 4.47 & 0.10 & 0.96 \\
\hline Total VFA ${ }^{2}$ & $\mathrm{mM} \mathrm{L} \mathrm{L}^{-1}$ & 103.8 & 109.0 & 8.72 & 0.52 \\
\hline Individual VFA & mol $100 \mathrm{~mol}^{-1}$ total VFA & & & & \\
\hline Acetic acid & & 66.2 & 67.0 & 5.08 & 0.79 \\
\hline Propionic acid & & 21.8 & 25.4 & 3.81 & 0.38 \\
\hline Butyric acid & & 11.4 & 12.3 & 1.17 & 0.47 \\
\hline Isobutyric acid & & 0.89 & 0.80 & 0.08 & 0.39 \\
\hline Valeric acid & & 1.26 & 1.42 & 0.21 & 0.41 \\
\hline Isovaleric acid & & 1.55 & 1.57 & 0.14 & 0.77 \\
\hline Caproic acid & & 0.55 & 0.46 & 0.14 & 0.61 \\
\hline Enanthic acid & & 0.04 & 0.03 & 0.01 & 0.35 \\
\hline L-lactic acid & $\mathrm{m} M \mathrm{~L}^{-1}$ & 0.39 & 0.37 & 0.11 & 0.88 \\
\hline D-lactic acid & $\mathrm{m} M \mathrm{~L}^{-1}$ & 0.39 & 0.37 & 0.11 & 0.91 \\
\hline Total lactic acid & $\mathrm{m} M \mathrm{~L}^{-1}$ & 0.78 & 0.75 & 0.21 & 0.89 \\
\hline
\end{tabular}

1 Treatment (CTR is control cows; IMS is cows receiving a topdressing of the feeds with the immunostimulant Omnigen-AF $\left.{ }^{\circledR}\right) .{ }^{2}$ Total volatile fatty acids. ${ }^{3}$ Standard error $=$ larger standard error for the fixed effects.

Among mineral metabolism biomarkers, the TRT $\times \mathrm{t}$ interaction for $\mathrm{Zn}$ trended toward significance $(p=0.08$; Figure 3e). Its concentration was higher in the IMS group than in the CTR group at -53 DFC $(p<0.01)$ and tended to be higher at -21 and 42 DFC $(p<0.10)$. No effect was detected on the concentration of other minerals (Supplementary File $3 \mathrm{e}-\mathrm{j}$ ).

\subsubsection{Liver Function and Inflammation Biomarkers}

No effect was detected on liver enzyme biomarkers (Supplementary Files 3k-1 and 4a-b). Among inflammation biomarkers, globulin and total proteins were not affected (Supplementary File 5a-b), whereas myeloperoxidase experienced a TRT $\times \mathrm{t}$ interaction effect $(p=0.02$; Figure 3f). Cows treated with OAF had lower concentration of this enzyme at -21 and -14 DFC $(p<0.05)$. None of the positive acute phase proteins (APP) were affected by OAF (Supplementary File $4 \mathrm{e}-\mathrm{g}$ ). Among negative APP, a TRT $\times \mathrm{t}$ interaction appeared for albumin $(p=0.05$, Figure $3 \mathrm{~g})$ and cholesterol $(p=0.04$; Figure $3 \mathrm{~h})$. The albumin concentration was lower in the IMS group than in the CTR group at -3 and 3 DFC $(p<0.05)$ and tended to be lower at 14 and 28 DFC ( $p<0.10)$; in contrast, cholesterol concentration tended to be higher in the IMS group than in the CTR group at -53 DFC $(p<0.10)$. Concentrations of retinol and PON (Supplementary File $4 \mathrm{~h}-\mathrm{i}$ ) as well as those of IL-1B and IL-6 (Supplementary File 4c-d) were not affected by OAF.

\subsubsection{Oxidative Status Biomarkers}

Among antioxidant capacity indicators, SHp and FRAP had a TRT $\times \mathrm{t}$ interaction $(p<0.01$; Figures $3 \mathrm{i}$ and $4 \mathrm{a}$ ). Compared to the CTR group, IMS cows had a lower concentration of SHp from -3 to 28 DFC $(p<0.05)$ and a lower concentration of FRAP at 3 DFC $(p<0.01)$. No effect was detected for tocopherol, beta-carotene, or ORAC concentration (Supplementary File 5c-e).

Among oxidant species, ROM had a TRT $\times$ t interaction $(p<0.01$; Figure $4 \mathrm{~b})$ and tended to be lower in the IMS group than in the CTR group at -28 DFC $(p<0.10)$, whereas nitrogen species were not affected (Supplementary File 5f-h). The ROMt/FRAP ratio was not affected (Figure 4c) whereas AOPP was affected by TRT ( $p=0.02)$ and tended to experience a TRT $\times \mathrm{t}$ interaction effect $(p=0.09$; Figure $4 \mathrm{~d})$. AOPP was lower in the IMS group than in the CTR group at $-48,-3,1$, and 3 DFC $(p<0.05)$. 


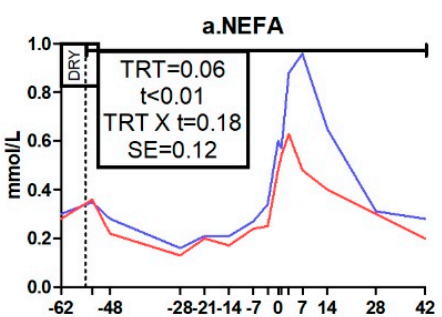

DFC

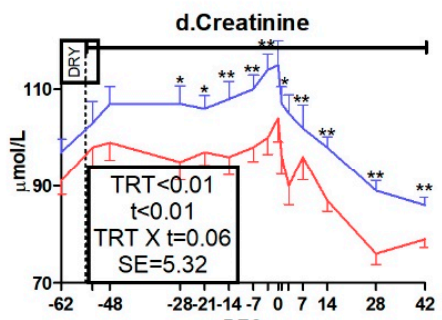

DFC

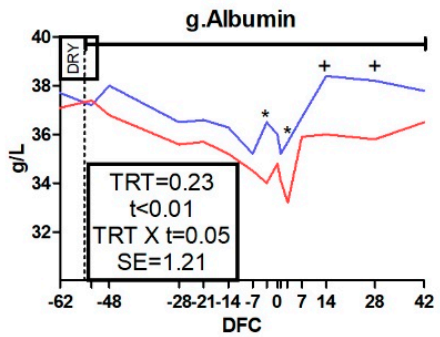

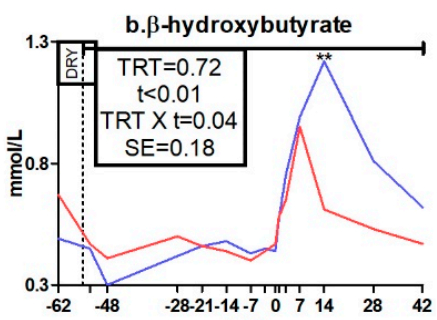

DFC

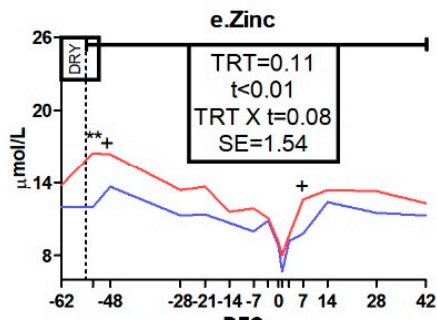

DFC

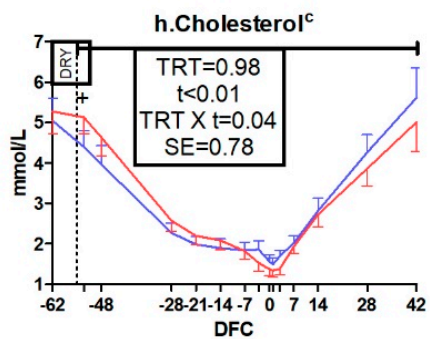

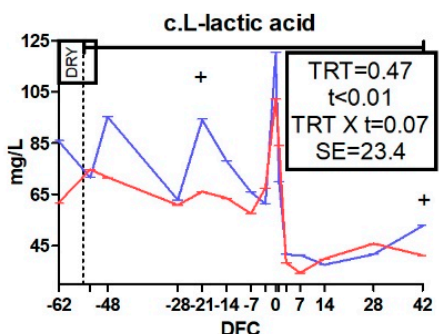

DFC

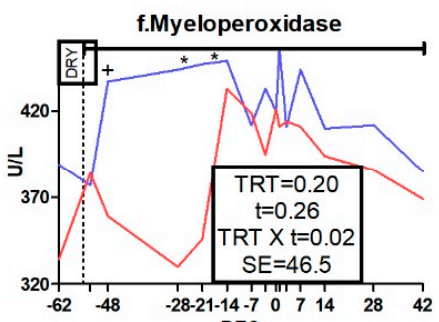

DFC

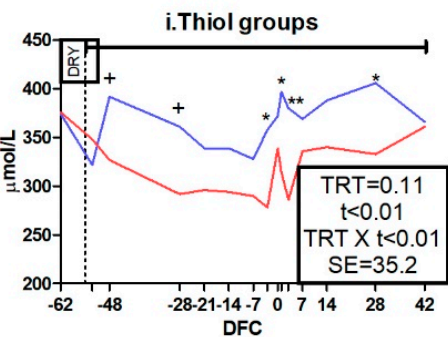

Figure 3. Time course of plasma concentrations of non-esterified fatty acids (NEFA; (a)), $\beta$-hydroxybutyrate (b), L-lactic acid (c), creatinine (d), zinc (e), myeloperoxidase (f), albumin (g), cholesterol (h), and thiol groups (i) in control dairy cows (CTR; blue line, $n=5$ ) and cows receiving $65 \mathrm{~g}^{*} \mathrm{~d}^{-1}$ of Omnigen-AF${ }^{\circledR}$ as top-dress (IMS; red line, $\mathrm{n}=5$ ) between -55 and 42 days from calving. Upper solid line indicates timing of treatment administration. TRT is treatment effect; $\mathrm{t}$ is time effect; TRT $\times \mathrm{t}$ is the treatment $\times$ time interaction effect $\left({ }^{* *}\right.$ is $p<0.01{ }^{*}$ is $p<0.05 ;+$ is $\left.p<0.10\right)$. DFC is days from calving; DRY is dry-off day ( -55 days from expected calving); SE is standard error; ${ }^{c}$ Parameter was covariate on -62 value.

\subsection{Blood Cell Profile}

In the blood cell profile (Table 4 ), the mean cell volume and mean cell hemoglobin tended to be lower in IMS cows than in the CTR group $(p=0.08)$. The number of platelets tended to be higher and the mean platelet volume was lower in the IMS group than in the CTR group $(p=0.07$ and $=$ 0.01 , respectively). A TRT $\times \mathrm{t}$ interaction also appeared for mean platelet volume $(p<0.01)$ : In IMS cows, volume was lower at -48 and $-1(p<0.05)$ and tended to be lower at 7 DFC $(p<0.10)$ in comparison to CTR cows. No differences appeared for total leukocytes, neutrophils, lymphocytes, and hemoglobin (Table 4), and neither for neutrophil to lymphocyte ratio, eosinophils, red blood cells, mean cell hemoglobin concentration, or red blood cell distribution width (data not shown).

\subsection{Whole Blood Stimulation Assay, Interferon Gamma Release Assay, and Carrageenan Skin Test}

OAF treatment did not affect the cytokine response in WBA (Table 5). A tendency for a TRT $\times \mathbf{t}$ interaction appeared for fold changes of glucose, DLA, and LLA ( $p=0.06,0.08$ and 0.10 , respectively; Table 6). The fold change of glucose tended to be higher in the IMS group than in the CTR group at -21 DFC $(p<0.10)$ and was higher at 7 DFC $(p<0.01)$. The fold change of DLA $(p<0.10)$ and that of LLA were lower $(p<0.05)$ in IMS cows than in the CTR group at 28 DFC. The response to LPS stimulation of nitrogen metabolites (Table 7), the response to IFNG release assay and the total response to CST (Supplementary File 6a,b) were not affected by OAF treatment. 

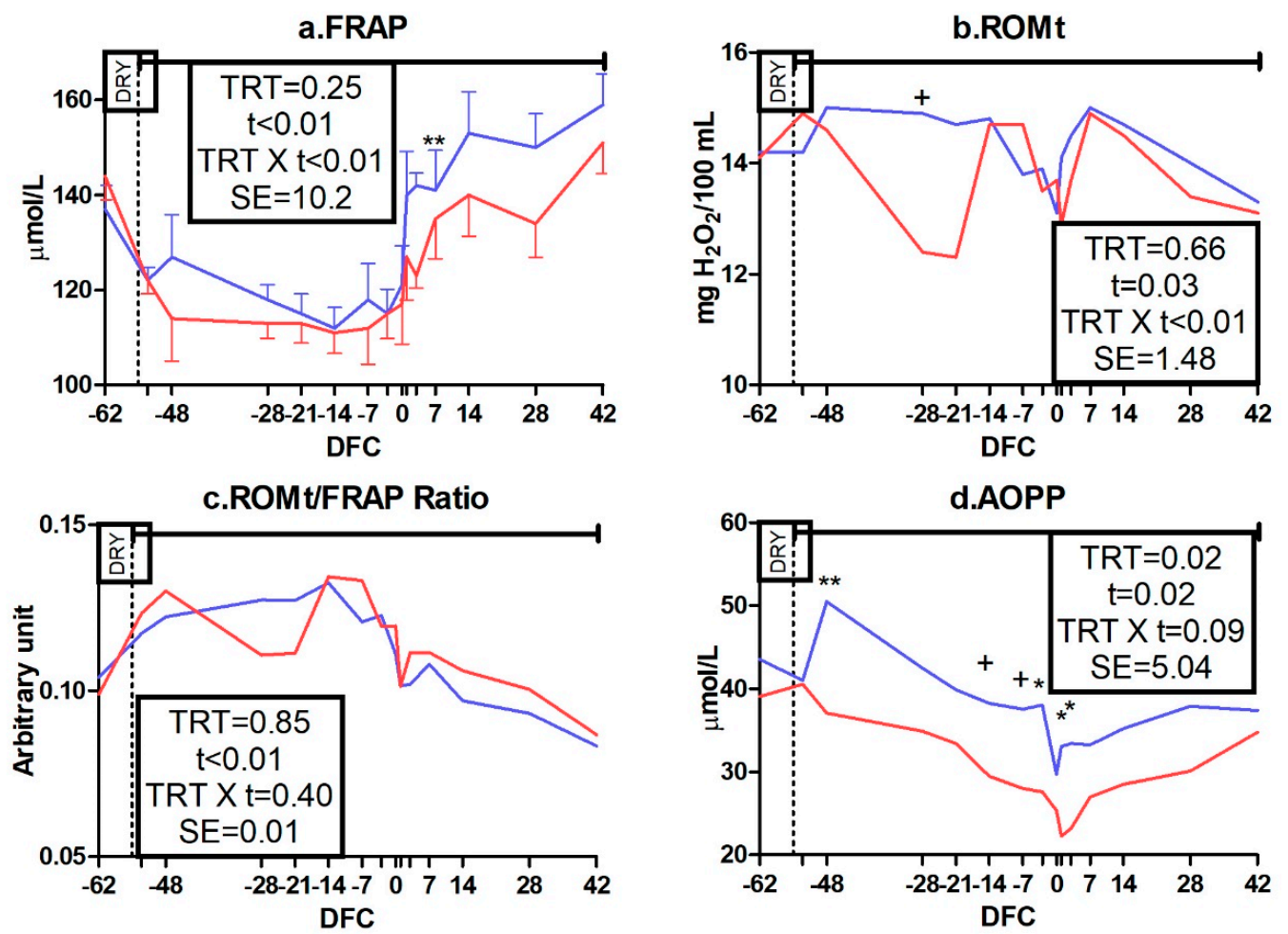

Figure 4. Time course of plasma concentrations of ferric-reducing antioxidant power (FRAP; (a)), total reactive oxygen metabolites $(\mathrm{ROMt} ;(\mathbf{b}))$, reactive oxygen metabolites to ferric-reducing antioxidant power ratio (ROMt/FRAP ratio; $(\mathbf{c})$ ) and advanced oxidation of proteins product (AOPP; $(\mathbf{d}))$ in control dairy cows (CTR; blue line, $\mathrm{n}=5$ ) and cows receiving $65 \mathrm{~g}^{*} \mathrm{~d}^{-1}$ of Omnigen-AF ${ }^{\circledR}$ as top-dress (IMS; red line, $n=5$ ) between -55 and 42 days from calving. Upper solid line indicates timing of treatment administration. TRT is treatment effect; $\mathrm{t}$ is time effect; TRT $\times \mathrm{t}$ is the treatment $\times$ time interaction effect (** is $p<0.01 ;{ }^{*}$ is $p<0.05 ;+$ is $\left.p<0.10\right)$. DFC is days from calving; DRY is dry-off day ( -55 days from expected calving); $\mathrm{SE}$ is standard error.

Table 4. Blood cells profile in control dairy cows $(n=5)$ or cows receiving $65 \mathrm{~g}^{*} \mathrm{~d}^{-1}$ of Omnigen-AF ${ }^{\circledR}$ as top-dress between -55 and 42 days from calving $(n=5)$.

\begin{tabular}{|c|c|c|c|c|c|c|c|c|c|c|c|}
\hline \multirow{2}{*}{ Item, Unit } & \multirow{2}{*}{ TRT $^{1}$} & \multicolumn{6}{|c|}{ Days from Calving } & \multirow{2}{*}{$S E^{2}$} & \multicolumn{3}{|c|}{$p$-Value } \\
\hline & & -62 & -48 & -21 & -3 & 7 & 28 & & TRT $^{1}$ & $t^{3}$ & TRT $\times t^{4}$ \\
\hline $\mathrm{WBC}^{5}$ & CTR & 6.4 & 5.8 & 6.3 & 7.7 & 6.0 & 5.9 & 0.77 & 0.54 & $<0.01$ & 0.59 \\
\hline $10^{3} \mu \mathrm{L}^{-1}$ & IMS & 7.5 & 6.6 & 6.8 & 8.4 & 6.8 & 5.7 & 0.77 & & & \\
\hline Neu ${ }^{6}$ & CTR & 3.3 & 3.0 & 3.2 & 4.7 & 3.6 & 3.2 & 0.61 & 0.52 & $<0.01$ & 0.69 \\
\hline $10^{3} \mu \mathrm{L}^{-1}$ & IMS & 4.0 & 3.3 & 3.5 & 5.1 & 3.9 & 3.0 & 0.61 & & & \\
\hline $\operatorname{Lym}^{7}$ & CTR & 2.2 & 2.0 & 2.2 & 2.2 & 1.7 & 1.9 & 0.59 & 0.56 & $<0.01$ & 0.04 \\
\hline $10^{3} \mu \mathrm{L}^{-1}$ & IMS & 2.7 & 2.6 & 2.6 & 2.3 & 2.2 & 2.0 & 0.61 & & & \\
\hline $\mathrm{HGB}^{8}$ & CTR & 10.8 & 11.4 & 10.6 & 11.0 & 10.7 & 9.8 & 0.40 & 0.20 & $<0.01$ & 0.42 \\
\hline $\mathrm{g} \mathrm{dL}^{-1}$ & IMS & 10.0 & 10.5 & 10.0 & 10.2 & 10.4 & 9.4 & 0.40 & & & \\
\hline $\mathrm{MCV}^{9}$ & CTR & 48.3 & 48.6 & 48.6 & 51.0 & 49.6 & 48.7 & 1.4 & 0.08 & $<0.01$ & 0.78 \\
\hline $\mathrm{fL}$ & IMS & 45.8 & 45.5 & 45.9 & 47.5 & 47.6 & 46.8 & 1.4 & & & \\
\hline $\mathrm{MCH}^{10}$, & CTR & 16.5 & 16.9 & 16.9 & 17.2 & 17.1 & 16.9 & 0.47 & 0.08 & 0.06 & 0.69 \\
\hline pg & IMS & 15.7 & 15.7 & 16.0 & 16.5 & 16.4 & 16.4 & 0.47 & & & \\
\hline PLT $^{11}$ & CTR & 323.8 & 273.6 & 280.0 & 305.8 & 313.8 & 420.4 & 38.2 & 0.07 & 0.02 & 0.84 \\
\hline $10^{3} \mu \mathrm{L}^{-1}$ & IMS & 354.6 & 348.8 & 345.8 & 412.8 & 357.2 & 437.6 & 38.2 & & & \\
\hline $\mathrm{MPV}^{12}$ & CTR & 6.9 & 8.3 & 7.6 & 6.9 & 6.8 & 5.8 & 0.36 & 0.01 & 0.01 & 0.01 \\
\hline $\mathrm{fL}$ & IMS & 6.1 & 5.7 & 6.3 & 6.5 & 5.9 & 5.5 & 0.45 & & & \\
\hline & & & $* *$ & $*$ & & + & & & & & \\
\hline
\end{tabular}

${ }^{1}$ Treatment (CTR is control cows; IMS is cows receiving a topdressing of the feeds with the immunostimulant Omnigen-AF $\left.{ }^{\circledR}\right)$. ${ }^{2}$ Standard error $=$ larger standard error for the fixed effects. ${ }^{3}$ Time effect. ${ }^{4}$ Treatment $\times$ time interaction effect $\left(+\right.$ is $p<0.10 ;{ }^{*}$ is $p<0.05 ;{ }^{* *}$ is $p<0.01$ for differences among means within a column. These symbols are only presented when the interaction effect is significant). ${ }^{5}$ White blood cells. ${ }^{6}$ Neutrophils. ${ }^{7}$ Lymphocytes.

${ }^{8}$ Hemoglobin. ${ }^{9}$ Mean cell volume. ${ }^{10}$ Mean cell hemoglobin. ${ }^{11}$ Platelets. ${ }^{12}$ Mean platelet volume. 
Table 5. Fold change values (expressed with respect to baseline) of cytokines in a whole blood stimulation assay with a low or high dose of bacterial lipopolysaccharides in control dairy cows $(n=5)$ or cows receiving $65 \mathrm{~g}^{*} \mathrm{~d}^{-1}$ of Omnigen-AF${ }^{\circledR}$ as top-dress between -55 and 42 days from calving $(n=5)$.

\begin{tabular}{|c|c|c|c|c|c|c|c|c|c|c|c|c|c|c|}
\hline \multirow[b]{2}{*}{ Item } & \multirow[b]{2}{*}{$D^{2}$} & \multirow[b]{2}{*}{ TRT $^{1}$} & \multicolumn{6}{|c|}{ Days from Calving } & \multirow[b]{2}{*}{$\mathrm{SE}^{3}$} & \multicolumn{5}{|c|}{$p$-Value } \\
\hline & & & -62 & -45 & -21 & -3 & 7 & 28 & & TRT $^{1}$ & $t^{4}$ & $\mathrm{D}^{2}$ & $\begin{array}{l}\text { TRT } \\
\times t^{5}\end{array}$ & $\begin{array}{c}\text { TRT } \times t \\
\times D^{6}\end{array}$ \\
\hline \multirow{6}{*}{ IL-1 7} & \multirow{2}{*}{ Low } & CTR & 3.5 & 9.9 & 10.0 & 20.2 & 18.7 & 6.9 & \multirow[t]{2}{*}{11.3} & \multirow[t]{2}{*}{0.66} & \multirow[t]{2}{*}{$<0.01$} & \multirow[t]{2}{*}{$<0.01$} & \multirow[t]{2}{*}{0.13} & \multirow[t]{2}{*}{0.87} \\
\hline & & IMS & 5.2 & 9.9 & 13.1 & 10.2 & 9.8 & 9.7 & & & & & & \\
\hline & \multirow{2}{*}{ High } & CTR & 13.1 & 21.2 & 33.6 & 52.1 & 55.3 & 23.7 & \multirow[t]{2}{*}{11.3} & & & & & \\
\hline & & IMS & 20.0 & 40.9 & 39.9 & 51.8 & 59.6 & 32.3 & & & & & & \\
\hline & \multirow{2}{*}{ Total } & CTR & 8.3 & 15.5 & 21.8 & 36.1 & 37.0 & 15.3 & \multirow[t]{2}{*}{9.3} & & & & & \\
\hline & & IMS & 12.6 & 25.4 & 26.5 & 31.0 & 34.7 & 21.0 & & & & & & \\
\hline \multirow{6}{*}{ IL- $6^{8}$} & \multirow{2}{*}{ Low } & CTR & 1.34 & 1.61 & 1.27 & 1.92 & 1.57 & 1.91 & \multirow[t]{2}{*}{0.39} & 0.97 & \multirow[t]{6}{*}{0.06} & \multirow[t]{6}{*}{$<0.01$} & \multirow[t]{6}{*}{0.10} & \multirow[t]{6}{*}{0.95} \\
\hline & & IMS & 1.69 & 1.65 & 1.56 & 1.33 & 1.78 & 1.60 & & & & & & \\
\hline & \multirow{2}{*}{ High } & CTR & 1.90 & 2.19 & 1.99 & 2.10 & 2.40 & 3.07 & \multirow[t]{2}{*}{0.39} & & & & & \\
\hline & & IMS & 2.20 & 2.38 & 1.77 & 1.71 & 2.87 & 2.38 & & & & & & \\
\hline & \multirow{2}{*}{ Total } & CTR & 1.62 & 1.90 & 1.63 & 2.01 & 1.98 & 2.49 & \multirow[t]{2}{*}{0.31} & & & & & \\
\hline & & IMS & 1.95 & 2.01 & 1.67 & 1.52 & 2.32 & 1.99 & & & & & & \\
\hline
\end{tabular}

${ }^{1}$ Treatment (CTR is control cows; IMS is cows receiving a topdressing of the feeds with the immunostimulant Omnigen-AF ${ }^{\circledR}$ ). ${ }^{2}$ Dose (Total reflects the global effect of LPS stimulation, without accounting for the dose).

${ }^{3}$ Standard error $=$ larger standard error for the fixed effects. ${ }^{4}$ Time. ${ }^{5}$ Treatment $\times$ time interaction effect.

${ }^{6}$ Treatment $\times$ time $\times$ dose interaction effect. ${ }^{7}$ Interleukin- 1 beta. ${ }^{8}$ Interleukin- 6.

Table 6. Fold change values (expressed with respect to baseline) of energy metabolism biomarkers after a whole blood stimulation assay with a low or high dose of bacterial lipopolysaccharides in control dairy cows $(n=5)$ or cows receiving $65 \mathrm{~g}^{*} \mathrm{~d}^{-1}$ of Omnigen- $A F^{\circledR}$ as top-dress between -55 and 42 days from calving $(\mathrm{n}=5)$.

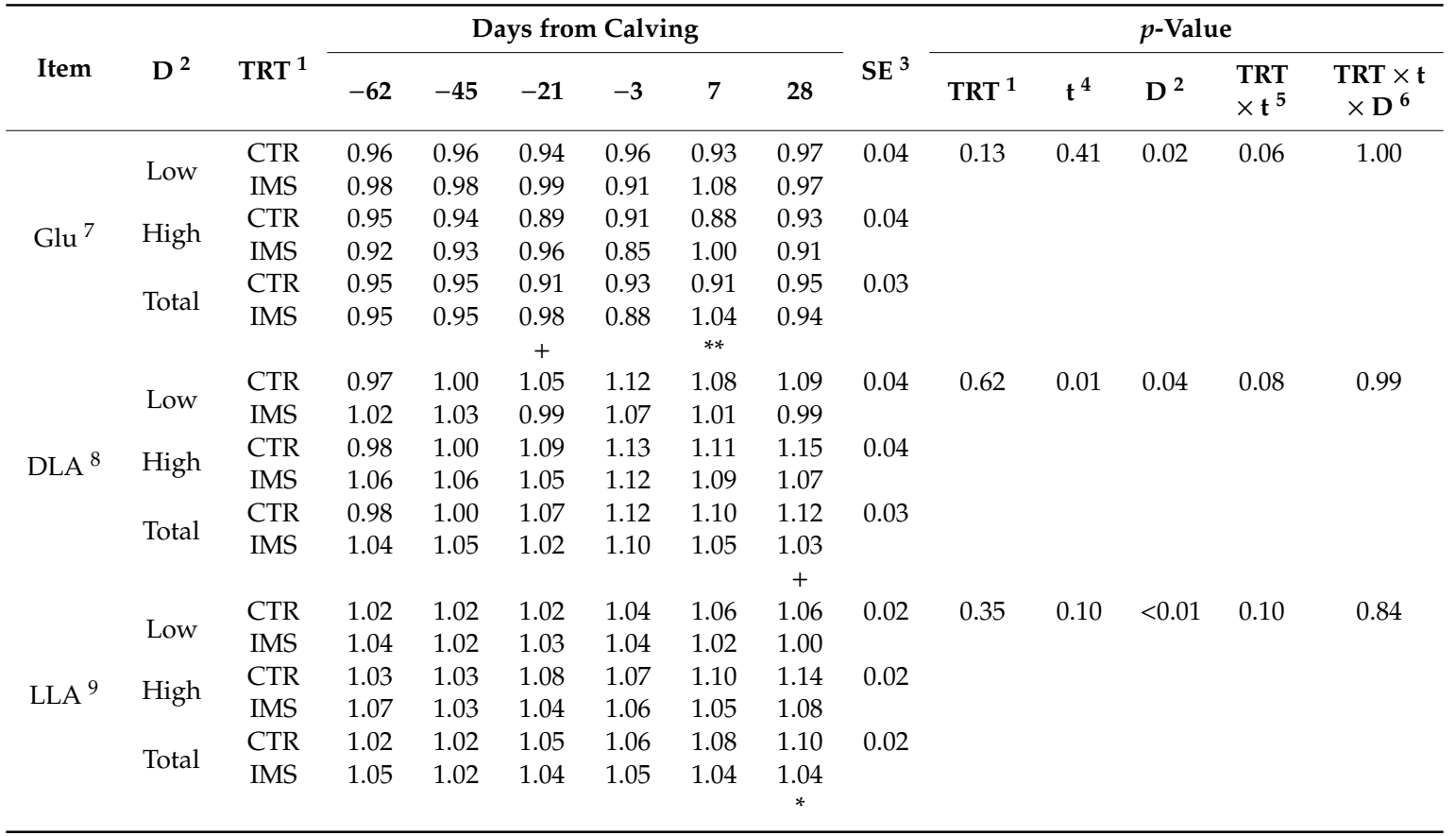

\footnotetext{
1 Treatment (CTR is control cows; IMS is cows receiving a topdressing of the feeds with the immunostimulant Omnigen-AF ${ }^{\circledR}$ ). ${ }^{2}$ Dose (Total reflects the global effect of LPS stimulation, without accounting for the dose).

${ }^{3}$ Standard error $=$ larger standard error for the fixed effects. ${ }^{4}$ Time. ${ }^{5}$ Treatment $\times$ time interaction effect $(+$ is $p<0.10 ;{ }^{*}$ is $p<0.05 ;{ }^{* *}$ is $p<0.01$ for differences among means within a column. These symbols are only presented when the interaction effect is significant). ${ }^{6}$ Treatment $\times$ time $\times$ dose interaction effect. ${ }^{7}$ Glucose. ${ }^{8}$ D-lactic acid.

9 L-lactic acid.
} 
Table 7. Fold change values (expressed with respect to baseline) of nitrogen species after a whole blood stimulation assay with a low or high dose of bacterial lipopolysaccharides in control dairy cows $(n=5)$ or cows receiving $65 \mathrm{~g}^{*} \mathrm{~d}^{-1}$ of Omnigen-AF${ }^{\circledR}$ as top-dress between -55 and 42 days from calving $(n=5)$.

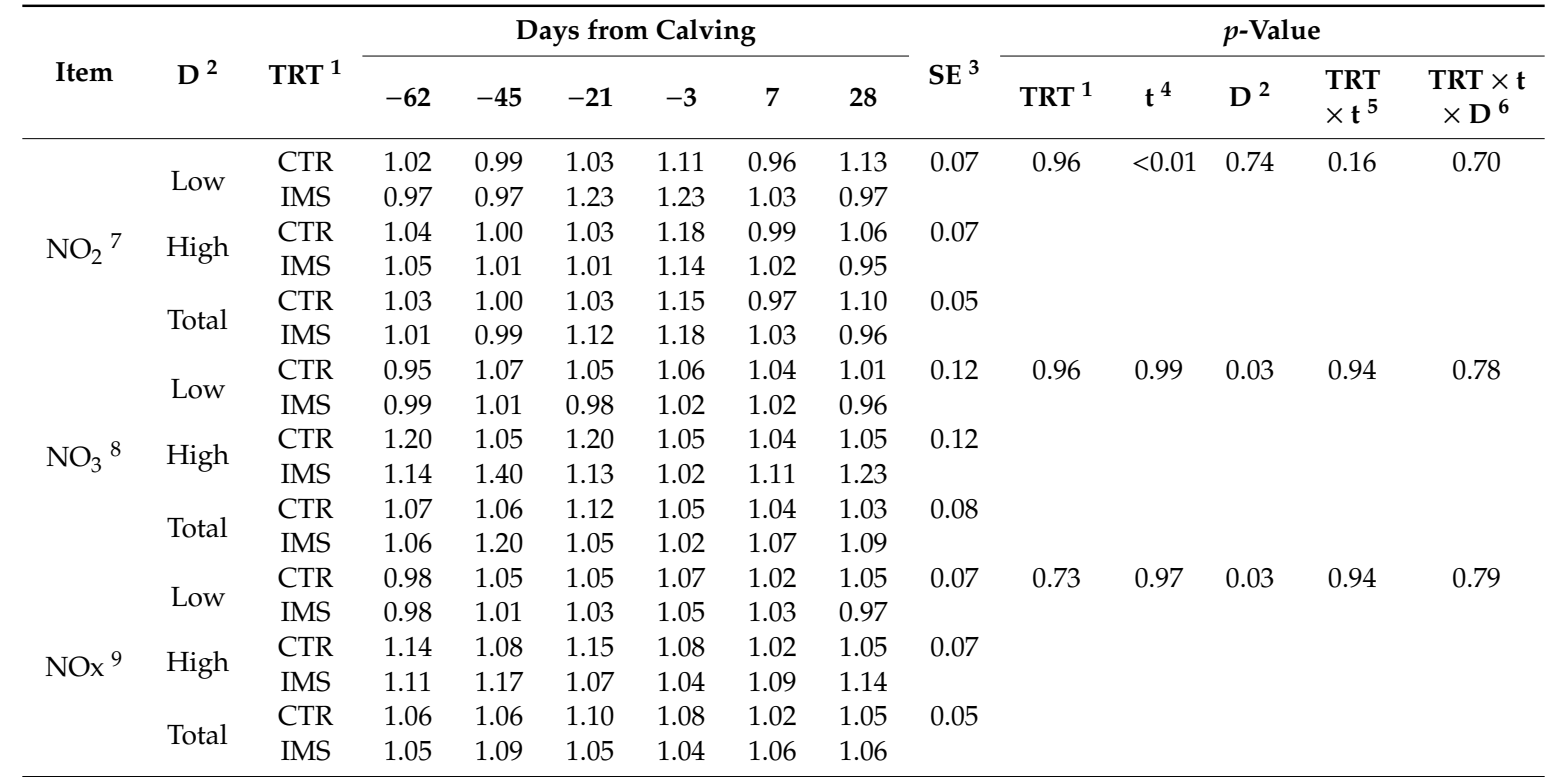

\footnotetext{
${ }^{1}$ Treatment (CTR is control cows; IMS is cows receiving a topdressing of the feeds with the immunostimulant Omnigen-AF${ }^{\circledR}$ ). ${ }^{2}$ Dose (Total reflects the global effect of LPS stimulation, without accounting for the dose).

${ }^{3}$ Standard error $=$ larger standard error for the fixed effects. ${ }^{4}$ Time. ${ }^{5}$ Treatment $\times$ time interaction effect. ${ }^{6}$ Treatment $x$ time $\times$ dose interaction effect. ${ }^{7}$ Nitrite. ${ }^{8}$ Nitrate. ${ }^{9}$ Nitric oxide.
}

\section{Discussion}

Administration of OAF did not affect BW, BCS, or milk yield in our experiment, confirming previous results $[18,20]$. Furthermore, the lack of differences in milk composition suggests OAF to have no direct effects on metabolic functions under homeostasis condition. Nevertheless, the lower NEFA and BHB concentration found in IMS animals after calving suggests OAF to have reduced lipomobilization and hepatic ketogenesis. Such a positive effect on lipid metabolism could be directly induced by niacin and choline contained in OAF. Niacin reduces hepatic lipolysis, and choline reduces triglyceride abundance and fat infiltration in the liver [39]; supplementation of these two compounds during the transition period has been previously reported to reduce blood NEFA and BHB concentrations in dairy cows [40,41].

The higher rumination time found in IMS cows in early lactation suggests OAF improved the recovery of rumen motility after the severe digestive and metabolic challenges that are widely reported during transition period $[42,43]$. This could be consequential to the modulatory effect that the yeasts and fungal cell walls composing OAF exert on rumen fermentation; however, the collection time of our rumen samples makes it difficult to elucidate the effect of the additive on rumen fermentation after the sudden alterations related to calving. Our samples were collected before morning feeding at $28 \mathrm{DFC}$, long after the occurrence of alterations related to calving and when fermentation patterns were at their nadir. Thus, the lack of any increase in VFA production with OAF does not dismiss its role in modulating rumen fermentation because such higher production could have been balanced by higher absorption. The amelioration in lipid metabolism with OAF could be hypothesized to partially contribute to the improved rumination time. In fact, 3 out of 5 of our CTR cows developed sub-clinical ketosis in early lactation (blood BHB $>1.4 \mathrm{mmol} / \mathrm{L}$ ), and the higher rumination time found in our IMS cattle could be consequential to the inhibitory effect of ketosis on rumination activity [44] in our CTR cows. Despite that, the number of animals included in our experiment and the low statistical power found for rumination time measurements suggests care in the interpretation of such a founding. 
The improved rumination activity and lipid metabolism in early lactation could account for the effectiveness of OAF in favoring the recovery of normal body functions after stress [6], suggesting it to be effective in preventing the metabolic disorders of TP. These positive effects on lipid metabolism and rumination could also account for the effectiveness of OAF in improving leukocyte functions [45-47]. Both NEFA and BHB are known to impair the viability of white blood cells $[1,48,49]$, and their reduction could explain the lower lactate production and higher glucose concentration found in the blood of IMS cows after LPS stimulation of leukocytes. Production of lactate by neutrophils and monocytes is known to impair the motility, killing capacity and effector functions of leukocytes and suppressing the inflammasome and the production of pro-inflammatory cytokines $[1,50]$. Thus, a lower production of this metabolite in activated leukocytes could reflect greater immune competence. The lower glucose consumption after stimulation with LPS could be driven by more efficient metabolism in leukocytes while they cope with a biological stressor, reflecting improved killing capacity of those cells. This is also consistent with the previously reported effectiveness of OAF in improving phagocytosis, ROM production, and respiratory burst activity of PMN [19].

With these positive effects on lipomobilization and white blood cell function, an improvement in liver function and faster resolution of inflammatory phenomena, reflected in the typical trends of plasma indicators [51], were expected at a metabolic level with OAF supplementation. Nevertheless, the circulating concentration of IL-1B and IL-6 and their level after the ex vivo stimulation of leukocytes with LPS were not affected by the treatment, even though the augmented expression of genes triggered by toll-like receptors in PMNs has been widely reported as a main effect of OAF [6]. Furthermore, OAF did not affect the blood concentration of $\alpha$-globulins (haptoglobin, ceruloplasmin, and SAA), called positive APP because their hepatic synthesis increases during inflammation [52]. Less clear is the effect of OAF on albumin, PON, and lipoprotein concentrations. These indicators are called negative APP because they decrease during inflammation due to the shift of liver synthesis on positive APP [53].

Our IMS animals tended to have a higher concentration of cholesterol in the early-dry period, reflecting greater hepatic synthesis of lipoproteins [54] and a better liver condition. A possible explanation for such an effect of OAF could be the contribution of vitamin B12 in increasing phospholipid concentrations in the blood [55]. The tendency for lower blood ROMt concentrations suggests lower production of oxidant species in our IMS cows during the dry period, which might have arisen from a less marked leukocyte activation in the peripheral blood, as suggested by the reduced myeloperoxidase and AOPP concentrations detected in the same time frame. In fact, myeloperoxidase generates hypochlorous acid that is converted into ROM within the respiratory burst [15,56], and AOPP are markers of protein oxidation triggered by this metabolite [57]. Such an anti-oxinflammatory effect exerted by OAF before calving could arise from better stabilization of PMN and monocytes, which need a stronger stimulus to mount an inflammatory reaction in IMS animals. Furthermore, the tendency for a lower production of ROM could suggest a more efficient oxidative phosphorylation pathway, in accordance with [6].

On the other hand, our IMS animals had lower levels of albumin, SHp, and FRAP in early lactation in comparison to CTR cows. These compounds are known to exert antioxidant activities: Albumin has a role in ligand binding and free radical trapping [58]; blood SHp mainly reflects albumin, lipoic acid, glutathione, and cysteine concentration; and FRAP provides a measurement of antioxidant power via blood concentration of bilirubin, uric acid, proteins, and vitamins $C$ and E [59]. As antioxidant capacity directly depends on liver activity $[15,60]$, dysregulation of the liver functions involved in controlling blood concentrations of such compounds could account for their post-partum trends with OAF; however, the lack of an effect on the concentration of bilirubin or enzymes related to amino acid metabolism in the liver (AST-GOT, GGT, ALP) refute the occurrence of any impairment of liver function [61]. Thus, we may hypothesize that the depletion of antioxidant systems observed with OAF in early lactation could arise from weak antioxidant activity of the product. Antioxidant biosynthesis and release are regulated processes, and administration of weak oxidants is known to up-regulate endogenous antioxidant mechanisms [62]. Conversely, weak antioxidant activity exerted by OAF 
could have reduced requirements for endogenous antioxidant compounds, down-regulating their synthesis de-novo.

\section{Conclusions}

Administration of OAF during the dry period and into lactation did not affect BW, BCS, milk yield, or milk and rumen fluid composition, nor did it affect peripheral response to the CST, reflecting neutrophil diapedesis. Nevertheless, OAF increased the rumination time and reduced NEFA and BHB concentrations in the blood in early lactation. Such an effect could explain the greater efficiency of leukocytes in facing biological stressors during the peripartum, as suggested by the lower lactate production and lower glucose consumption of leukocytes after an LPS challenge. Despite these positive effects on immune cells, OAF appears ineffective in reducing the degree of inflammation resulting from calving. A reduced abundance of antioxidants (albumin, SHp, and FRAP) also occurred with OAF after calving, suggesting a weak antioxidant action of the product reduced bodily requirements for endogenous antioxidant synthesis, although the lack of any effect on the ROM/FRAP ratio suggests no effect on the oxidative stress status. Although no effect was detected on liver function and inflammation, positive effects of OAF in reducing lipomobilization, favoring the recovery of rumen functions and exerting a probable antioxidant effect in early lactation suggest it to be an effective strategy in attenuating metabolic disorders of the transition period.

The associations identified here in a small number of cows in one herd should be further investigated. In fact, the evaluation of OAF on a larger number of animals and during acute inflammatory events is required to fully elucidate its effects on inflammatory parameters and leukocytes function. Furthermore, a deeper investigation of rumen fluid composition, with collection of rumen samples immediately after calving and when rumen fermentation reaches its peak, is required to elucidate how the effect of OAF on rumen level could contribute to ameliorating metabolic conditions in early lactation.

Supplementary Materials: The following are available online at http://www.mdpi.com/2076-2615/9/9/619/s1.

Author Contributions: Conceptualization, M.M., A.M. and E.T.; methodology, A.M., F.P.-C. and E.T.; formal analysis, M.M. and A.M.; investigation, M.M. and A.M.; resources, E.T.; Writing-Original Draft preparation, M.M.; Writing-Review and Editing, A.M., E.T., G.G. and M.B.; visualization, M.M.; supervision, E.T., G.G. and M.B.; project administration, E.T.; funding acquisition, E.T.

Funding: This research received no external funding.

Acknowledgments: This work was conducted in the framework of projects supported by CREI (Romeo and Enrica Invernizzi Research Center of the Università Cattolica del S. Cuore) funded by the "Fondazione Romeo ed Enrica Invernizzi", Milan, Italy. The authors wish to convey sincere thanks and appreciation to professor Massimo Bionaz (Department of Animal and Rangeland Sciences, Oregon State University, Corvallis, OR 97331, USA) for precious suggestions provided during paper writing.

Conflicts of Interest: The authors declare no conflict of interest. The funders had no role in the design of the study; in the collection, analyses, or interpretation of data; in the writing of the manuscript, or in the decision to publish the results.

\section{References}

1. Sordillo, L.M. Nutritional strategies to optimize dairy cattle immunity. J. Dairy Sci. 2016, 99, 4967-4982. [CrossRef] [PubMed]

2. Janeway, C.A.; Travers, P.; Walport, M.; Shlomchik, M. Immunobiology: The Immune System in Health and Disease, 6th ed.; Garland Science Publishing: New York, NY, USA, 2005.

3. Paape, M.J.; Bannerman, D.D.; Zhao, X.; Lee, J.W. The bovine neutrophil: structure and function in blood and milk. Vet. Res. 2003, 34, 597-627. [PubMed]

4. Forsberg, N.E. Recent insights into ruminant immune function: effects of stress and immunostimulatory nutritional products. In Proceedings 2004 Florida Ruminant Nutrition Symposium; University of Florida: Gainesville, FL, USA, 2004; pp. 81-92. 
5. Sordillo, L.M.; Streicher, K.L. Mammary gland immunity and mastitis susceptibility. J. Mammary Gland Biol. Neoplasia 2002, 7, 135-146. [CrossRef] [PubMed]

6. Nace, E.L.; Nickerson, S.C.; Kautz, F.M.; Breidling, S.; Wochele, D.; Ely, L.O.; Hurley, D.J. Modulation of innate immune function and phenotype in bred dairy heifers during the periparturient period induced by feeding an immunostimulant for 60 days prior to delivery. Vet. Immunol. Immunopathol. 2014, 161, 240-250. [CrossRef] [PubMed]

7. Jahan, N.; Minuti, A.; Trevisi, E. Assessment of immune response in periparturient dairy cows using ex vivo whole blood stimulation assay with lipopolysaccharides and carrageenan skin test. Vet. Immunol. Immunopathol. 2015, 165, 119-126. [CrossRef] [PubMed]

8. Shuster, D.E.; Lee, E.K.; Kehrli, M.E. Bacterial growth, inflammatory cytokine production, and neutrophil recruitment during coliform mastitis in cows within ten days after calving, compared with cows at midlactation. Am. J. Vet. Res. 1996, 57, 1569-1575. [PubMed]

9. Mallard, B.A.; Dekkers, J.C.; Ireland, M.J.; Leslie, K.E.; Sharif, S.; Lacey Vankampen, C.; Wagter, L.; Wilkie, B.N. Alteration in immune responsiveness during the peripartum period and its ramification on dairy cow and calf health. J. Dairy Sci. 1998, 81, 585-595. [CrossRef]

10. Trevisi, E.; Jahan, N.; Bertoni, G.; Ferrari, A.; Minuti, A. Pro-inflammatory cytokine profile in dairy cows: consequences for new lactation. Ital. J. Anim. Sci. 2015, 14, 285-292. [CrossRef]

11. Putman, A.K.; Brown, J.L.; Gandy, J.C.; Wisnieski, L.; Sordillo, L.M. Changes in biomarkers of nutrient metabolism, inflammation, and oxidative stress in dairy cows during the transition into the early dry period. J. Dairy Sci. 2018, 101, 9350-9359. [CrossRef]

12. Bionaz, M.; Trevisi, E.; Calamari, L.; Librandi, F.; Ferrari, A.; Bertoni, G. Plasma paraoxonase, health, inflammatory conditions, and liver function in transition dairy cows. J. Dairy Sci. 2007, 90, 1740-1750. [CrossRef]

13. Trevisi, E.; Amadori, M.; Cogrossi, S.; Razzuoli, E.; Bertoni, G. Metabolic stress and inflammatory response in high-yielding, periparturient dairy cows. Res. Vet. Sci. 2012, 93, 695-704. [CrossRef] [PubMed]

14. Drackley, J.K. Biology of dairy cows during the transition period: the final frontier? J. Dairy Sci. 1999, 82, 2259-2273. [CrossRef]

15. Celi, P. Oxidative stress in ruminants. In Studies on Veterinary Medicine. Oxidative Stress in Applied Basic Research and Clinical Practice; Mandelker, L., Vajdovich, P., Eds.; Humana Press: Totowa, NJ, USA, 2011; pp. 191-231. ISBN 978-1-61779-070-6.

16. Curtis, C.R.; Erb, H.N.; Sniffen, C.J.; Smith, R.D.; Kronfeld, D.S. Path analysis of dry period nutrition, postpartum metabolic and reproductive disorders, and mastitis in Holstein cows. J. Dairy Sci. 1985, 68, 2347-2360. [CrossRef]

17. Suriyasathaporn, W.; Daemen, A.J.J.M.; Noordhuizen-Stassen, E.N.; Dieleman, S.J.; Nielen, M.; Schukken, Y.H. $\beta$-hydroxybutyrate levels in peripheral blood and ketone bodies supplemented in culture media affect the in vitro chemotaxis of bovine leukocytes. Vet. Immunol. Immunopathol. 1999, 68, 177-186. [CrossRef]

18. Wang, Y.; Puntenney, S.B.; Burton, J.L.; Forsberg, N. Ability of a commercial feed additive to modulate expression of innate immunity in sheep immunosuppressed with dexamethasone. Animal 2007, 1, 945. [CrossRef] [PubMed]

19. Wang, Y.Q.; Puntenney, S.B.; Burton, J.L.; Forsberg, N.E. Use of gene profiling to evaluate the effects of a feed additive on immune function in periparturient dairy cattle. J. Anim. Physiol. Anim. Nutr. 2009, 93, 66-75. [CrossRef] [PubMed]

20. Ryman, V.E.; Nickerson, S.C.; Kautz, F.M.; Hurley, D.J.; Ely, L.O.; Wang, Y.Q.; Forsberg, N.E. Effect of dietary supplementation on the antimicrobial activity of blood leukocytes isolated from Holstein heifers. Res. Vet. Sci. 2013, 95, 969-974. [CrossRef] [PubMed]

21. Ohno, H. Intestinal M cells. J. Biochem. 2016, 159, 151-160. [CrossRef] [PubMed]

22. Wang, Y.Q.; Puntenney, S.B.; Forsberg, N.E. Identification of the mechanisms by which OmniGen-AF ${ }^{\circledR}$, a nutritional supplement, augments immune function in ruminant livestock. Am. Soc. Anim. Sci. West. Sect. 2004, 55, 349-352.

23. Revelo, X.S.; Davis, J.W.; Schnabel, R.D.; Kenny, A.L.; Barkley, N.M.; Waldron, M.R. Effects of an immunomodulatory dietary supplement on the global gene expression profile of neutrophils from periparturient dairy cows. J. Dairy Sci. 2013, 96, 485. 
24. Agricultural Development and Advisory Service Condition scoring of dairy cows. In Proceedings of the Pubblication 612; Ministry of Agriculture, Fisheries Food: Northumberland, UK, 1986.

25. Soriani, N.; Trevisi, E.; Calamari, L. Relationships between rumination time, metabolic conditions, and health status in dairy cows during the transition period. J. Anim. Sci. 2012, 90, 4544-4554. [CrossRef] [PubMed]

26. Sheldon, I.M.; Lewis, G.S.; LeBlanc, S.; Gilbert, R.O. Defining postpartum uterine disease in cattle. Theriogenology 2006, 65, 1516-1530. [CrossRef]

27. Ireland-Perry, R.L.; Stallings, C.C. Fecal consistency as related to dietary composition in lactating holstein cows. J. Dairy Sci. 1993, 76, 1074-1082. [CrossRef]

28. Duffield, T.F. Subclinical ketosis in lactating dairy cattle. Vet. Clin. North Am. Food Anim. Pract. 2000, 16, 231-253. [CrossRef]

29. Calamari, L.; Ferrari, A.; Minuti, A.; Trevisi, E. Assessment of the main plasma parameters included in a metabolic profile of dairy cow based on Fourier Transform mid-infrared spectroscopy: preliminary results. BMC Vet. Res. 2016, 12, 4. [CrossRef] [PubMed]

30. Jacometo, C.B.; Osorio, J.S.; Socha, M.; Corrêa, M.N.; Piccioli-Capelli, F.; Trevisi, E.; Loor, J.J. Maternal consumption of organic trace minerals (4-Plex) alters calf systemic and neutrophil mRNA and microRNA indicators of inflammation and oxidative stress. J. Dairy Sci. 2015, 98, 7717-7729. [CrossRef] [PubMed]

31. Minuti, A.; Ahmed, S.; Trevisi, E.; Piccioli-Cappelli, F.; Bertoni, G.; Jahan, N.; Bani, P. Experimental acute rumen acidosis in sheep: consequences on clinical, rumen, and gastrointestinal permeability conditions and blood chemistry. J. Anim. Sci. 2014, 92, 3966-3977. [CrossRef] [PubMed]

32. Bradley, P.P.; Priebat, D.A.; Christensen, R.D.; Rothsein, G. Measurement of cutaneous inflammation: estimation of neutrophil content with an enzyme marker. J. Invest. Dermatol. 1982, 78, 206-209. [CrossRef]

33. Hanasand, M.; Omdal, R.; Norheim, K.B.; Gøransson, L.G.; Brede, C.; Jonsson, G. Improved detection of advanced oxidation protein products in plasma. Clin. Chim. Acta 2012, 413, 901-906. [CrossRef]

34. Ling, T.; Hernandez-Jover, M.; Sordillo, L.M.; Abuelo, A. Maternal late-gestation metabolic stress is associated with changes in immune and metabolic responses of dairy calves. J. Dairy Sci. 2018, 101, 6568-6580. [CrossRef]

35. Trevisi, E.; Amadori, M.; Riva, F.; Bertoni, G.; Bani, P. Evaluation of innate immune responses in bovine forestomachs. Res. Vet. Sci. 2014, 96, 69-78. [CrossRef]

36. Calamari, L.; Petrera, F.; Bertin, G. Effects of either sodium selenite or Se yeast (Sc CNCM I-3060) supplementation on selenium status and milk characteristics in dairy cows. Livest. Sci. 2010, 128, 154-165. [CrossRef]

37. Chessa, S.; Bulgari, O.; Rizzi, R.; Calamari, L.; Bani, P.; Biffani, S.; Caroli, A.M. Selection for milk coagulation properties predicted by Fourier transform infrared spectroscopy in the Italian Holstein-Friesian breed. J. Dairy Sci. 2014, 97, 4512-4521. [CrossRef] [PubMed]

38. Littell, R.C.; Henry, P.R.; Ammerman, C.B. Statistical analysis of repeated measures data using SAS procedures. J. Anim. Sci. 1998, 76, 1216. [CrossRef] [PubMed]

39. Zhou, Z.; Bulgari, O.; Vailati-Riboni, M.; Trevisi, E.; Ballou, M.A.; Cardoso, F.C.; Luchini, D.N.; Loor, J.J. Rumen-protected methionine compared with rumen-protected choline improves immunometabolic status in dairy cows during the peripartal period. J. Dairy Sci. 2016, 99, 8956-8969. [CrossRef] [PubMed]

40. Morey, S.D.; Mamedova, L.K.; Anderson, D.E.; Armendariz, C.K.; Titgemeyer, E.C.; Bradford, B.J. Effects of encapsulated niacin on metabolism and production of periparturient dairy cows. J. Dairy Sci. 2011, 94, 5090-5104. [CrossRef] [PubMed]

41. Esposito, G.; Irons, P.C.; Webb, E.C.; Chapwanya, A. Interactions between negative energy balance, metabolic diseases, uterine health and immune response in transition dairy cows. Anim. Reprod. Sci. 2014, 144, 60-71. [CrossRef] [PubMed]

42. Trevisi, E.; Grossi, P.; Piccioli-Cappelli, F.; Cogrossi, S.; Bertoni, G. Attenuation of inflammatory response phenomena in periparturient dairy cows by the administration of an omega-3 rumen protected supplement containing vitamin E. Ital. J. Anim. Sci. 2011, 10, 277-285. [CrossRef]

43. Van Knegsel, A.T.M.; Hammon, H.M.; Bernabucci, U.; Bertoni, G.; Bruckmaier, R.M.; Goselink, R.M.A.; Gross, J.J.; Kuhla, B.; Metges, C.C.; Parmentier, H.K.; et al. Metabolic adaptation during early lactation: key to cow health, longevity and a sustainable dairy production chain. CAB Rev. Perspect. Agric. Vet. Sci. Nutr. Nat. Resour. 2014, 9, 1-15. [CrossRef] 
44. Kaufman, E.I.; LeBlanc, S.J.; McBride, B.W.; Duffield, T.F.; DeVries, T.J. Association of rumination time with subclinical ketosis in transition dairy cows. J. Dairy Sci. 2016, 99, 5604-5618. [CrossRef]

45. Burton, J.L.; Kehrli, M.E.; Kapil, S.; Horst, R.L. Regulation of L-selectin and CD18 on bovine neutrophils by glucocorticoids: effects of cortisol and dexamethasone. J. Leukoc. Biol. 1995, 57, 317-325. [CrossRef]

46. Rowson, A.D.; Wang, Y.Q.; Aalseth, E.; Forsberg, N.E.; Puntenney, S.B. Effects of an immunomodulatory feed additive on the development of mastitis in a mouse infection model using four bovine-origin isolates. Animal 2011, 5, 220-229. [CrossRef] [PubMed]

47. Hall, L.W.; Rivera, F.A.; Villar, F.; Chapman, J.D.; Long, N.M.; Collier, R.J. Evaluation of OmniGen-AF ${ }^{\circledR}$ in lactating heat-stressed Holstein cows. In Proceedings of the 25th Annual Florida Ruminant Nutrition Symposium; University of Florida: Gainesville, FL, USA, 2014; pp. 16-26.

48. Stevens, M.G.H.; Peelman, L.J.; De Spiegeleer, B.; Pezeshki, A.; Van De Walle, G.R.; Duchateau, L.; Burvenich, C. Differential gene expression of the toll-like receptor-4 cascade and neutrophil function in earlyand mid-lactating dairy cows. J. Dairy Sci. 2011, 94, 1277-1288. [CrossRef] [PubMed]

49. Calder, P.C. Feeding the immune system. Proc. Nutr. Soc. 2013, 72, 299-309. [CrossRef] [PubMed]

50. Zhang, G.; Hailemariam, D.; Dervishi, E.; Goldansaz, S.A.; Deng, Q.; Dunn, S.M.; Ametaj, B.N. Dairy cows affected by ketosis show alterations in innate immunity and lipid and carbohydrate metabolism during the dry off period and postpartum. Res. Vet. Sci. 2016, 107, 246-256. [CrossRef] [PubMed]

51. Castell, J.V.; Gómez-Lechón, M.J.; David, M.; Andus, T.; Geiger, T.; Trullenque, R.; Fabra, R.; Heinrich, P.C. Interleukin-6 is the major regulator of acute phase protein synthesis in adult human hepatocytes. FEBS Lett. 1989, 242, 237-239. [CrossRef]

52. Ceciliani, F.; Ceron, J.J.; Eckersall, P.D.; Sauerwein, H. Acute phase proteins in ruminants. J. Proteomics 2012, 75, 4207-4231. [CrossRef] [PubMed]

53. Bertoni, G.; Trevisi, E.; Han, X.; Bionaz, M. Effects of inflammatory conditions on liver activity in puerperium period and consequences for performance in dairy cows. J. Dairy Sci. 2008, 91, 3300-3310. [CrossRef] [PubMed]

54. Gruys, E.; Toussaint, M.J.M.; Niewold, T.A.; Koopmans, S.J. Acute phase reaction and acute phase proteins. J. Zhejiang Univ. Sci. 2005, 6, 1045-1056. [CrossRef] [PubMed]

55. Graulet, B.; Matte, J.J.; Desrochers, A.; Doepel, L.; Palin, M.-F.; Girard, C.L. Effects of Dietary Supplements of Folic Acid and Vitamin B12 on Metabolism of Dairy Cows in Early Lactation. J. Dairy Sci. 2007, 90, 3442-3455. [CrossRef] [PubMed]

56. Faith, M.; Sukumaran, A.; Pulimood, A.B.; Jacob, M. How reliable an indicator of inflammation is myeloperoxidase activity? Clin. Chim. Acta 2008, 396, 23-25. [CrossRef] [PubMed]

57. Celi, P.; Gabai, G. Oxidant/antioxidant balance in animal nutrition and health: the role of protein oxidation. Front. Vet. Sci. 2015, 2. [CrossRef] [PubMed]

58. Roche, M.; Rondeau, P.; Singh, N.R.; Tarnus, E.; Bourdon, E. The antioxidant properties of serum albumin. FEBS Lett. 2008, 582, 1783-1787. [CrossRef] [PubMed]

59. Benzie, I.F.; Strain, J.J. The ferric reducing ability of plasma (FRAP) as a measure of "antioxidant power": the FRAP assay. Anal. Biochem. 1996, 239, 70-76. [CrossRef] [PubMed]

60. Sordillo, L.M.; Aitken, S.L. Impact of oxidative stress on the health and immune function of dairy cattle. Vet. Immunol. Immunopathol. 2009, 128, 104-109. [CrossRef] [PubMed]

61. Rodriguez-Jimenez, S.; Haerr, K.J.; Trevisi, E.; Loor, J.J.; Cardoso, F.C.; Osorio, J.S. Prepartal standing behavior as a parameter for early detection of postpartal subclinical ketosis associated with inflammation and liver function biomarkers in peripartal dairy cows. J. Dairy Sci. 2018, 101, 8224-8235. [CrossRef] [PubMed]

62. Gesslbauer, B.; Bochkov, V. Biochemical targets of drugs mitigating oxidative stress via redox-independent mechanisms. Biochem. Soc. Trans. 2017, 45, 1225-1252. [CrossRef] [PubMed]

(C) 2019 by the authors. Licensee MDPI, Basel, Switzerland. This article is an open access article distributed under the terms and conditions of the Creative Commons Attribution (CC BY) license (http://creativecommons.org/licenses/by/4.0/). 